\title{
Prograde and retrograde $P-T$ evolution of a Variscan high- temperature eclogite, French Massif Central, Haut-Allier
}

\author{
Luc de Hoÿm de Marien ${ }^{1, *}$, Pavel Pitra ${ }^{1,2}$, Florence Cagnard ${ }^{3}$ and Benjamin Le Bayon ${ }^{3}$ \\ ${ }^{1}$ Univ Rennes, CNRS, Géosciences Rennes, UMR 6118, F-35000 Rennes, France \\ 2 Česká geologická služba, CZ-118 21 Prague 1, Czech Republic \\ ${ }^{3}$ Bureau de Recherches Géologiques et Minières-BRGM, 3 avenue Claude Guillemin, BP 36009, 45060 Orléans Cedex 2, France
}

Received: 3 October 2019 / Accepted: 30 April 2020

\begin{abstract}
The $P-T$ evolution of a mafic eclogite sample from the Haut-Allier was studied in order to constrain the dynamic of the Variscan subduction in the eastern French Massif Central. Three successive metamorphic stages M1, M2 and M3, are characterized by assemblages comprising garnet1-omphacitekyanite, garnet2-plagioclase, and amphibole-plagioclase, respectively, and define a clockwise $P-T$ path. These events occurred at the conditions of eclogite $\left(\mathrm{M} 1 ; \sim 20 \mathrm{kbar}, 650^{\circ} \mathrm{C}\right.$ to $\sim 22.5 \mathrm{kbar}, 850{ }^{\circ} \mathrm{C}$ ), highpressure granulite $\left(\mathrm{M} 2 ; 19.5 \mathrm{kbar}\right.$ and $\left.875^{\circ} \mathrm{C}\right)$ and high-temperature amphibolite facies $(\mathrm{M} 3 ;<9 \mathrm{kbar}, 750$ $850^{\circ} \mathrm{C}$ ), respectively. Pseudosection modelling of garnet growth zoning and mineralogy of the inclusions reveal a prograde M1 stage, first dominated by burial and then by near isobaric heating. Subsequent garnet1 resorption, prior to a renewed growth of garnet 2 is interpreted in terms of a decompression during M2. Highpressure partial melting is predicted for both the M1 temperature peak and M2. M3 testifies to further strong decompression associated with limited cooling. The preservation of garnet growth zoning indicates the short-lived character of the temperature increase, decompression and cooling cycle. We argue that such $P-T$ evolution is compatible with the juxtaposition of the asthenosphere against the subducted crust prior to exhumation driven by slab rollback.
\end{abstract}

Keywords: French Massif Central / eclogite / HP granulite / subduction / $P-T$ pseudosection / isobaric heating

Résumé - Évolution P-T prograde et rétrograde des éclogites varisques du Haut-Allier, Massif Central (France). Cette étude a pour but d'apporter des contraintes sur la dynamique de la zone de subduction varisque de l'est du Massif Central Français à travers l'étude de l'évolution $P-T$, notamment du trajet prograde, d'un échantillon d'éclogite mafique du Haut-Allier. Trois évènements métamorphiques, M1, M2 et M3, respectivement définis par des assemblages comprenant grenat1-omphacite-disthène, grenat2-clinopyroxène-plagioclase et amphibole-plagioclase, définissent une évolution $P-T$ horaire. Ces évènements métamorphiques traduisent la succession des conditions du faciès des éclogites (M1; 20 kbar, $650^{\circ} \mathrm{C}$ à $\sim 22.5 \mathrm{kbar}, 850^{\circ} \mathrm{C}$ ), des granulites de haute pression (M2; $19.5 \mathrm{kbar}, 875^{\circ} \mathrm{C}$ ), puis des amphibolites de haute température $\left(\mathrm{M} 3 ;<9 \mathrm{kbar}, 750-850^{\circ} \mathrm{C}\right)$. L'étude pétrologique de cet échantillon par l'analyse de la zonation du grenat, de la minéralogie des inclusions qu'il contient et de la modélisation des équilibres de phases (pseudosections), suggère que le premier évènement métamorphique (M1) est prograde et traduit un enfouissement, puis un réchauffement isobare. La résorption du grenat 1 à laquelle succède la croissance du grenat 2 est interprétée comme le résultat d'une décompression isotherme lors du métamorphisme M2. Il est suggéré que ces roches ont subi une fusion partielle lors du pic thermique du stade M1 et lors du stade M2. Le dernier évènement métamorphique traduit une forte décompression associée à un refroidissement limité. La préservation d'une importante zonation de croissance du grenat à de telles conditions de température traduit la brièveté de l'ensemble de l'évolution métamorphique et par conséquent, du réchauffement, de la décompression puis du refroidissement qui s'ensuit. Cette évolution des conditions $P-T$ est compatible avec un modèle géodynamique invoquant la juxtaposition du manteau asthénosphérique chaud contre les roches de la croûte subductée à laquelle succède une exhumation dominée par le retrait du panneau plongeant (slab rollback).

Mots clés : Massif Central Français / éclogites / granulites HP / subduction / pseudosection / réchauffement isobare

*Corresponding author: luc.dehoym@gmail.com 


\section{Introduction}

Eclogites exhumed in the core of orogens are commonly considered to evidence ancient subduction zones (e.g. Miyashiro, 1961, 1972; Godard, 2001; Ernst and Liou, 2008). As such, the pressure-temperature $(P-T)$ paths of Variscan eclogites in the French Massif Central place fundamental constraints on the earliest tectonometamorphic evolution of the orogen. Pioneering works on eclogites in the Massif Central revealed the shape of the retrograde $P-T$ path (either associated with cooling or heating in the western and eastern Massif Central, respectively) but the inferred maximum pressures were surprisingly low for a subduction environment (mostly 13-15 kbar; Mercier et al., 1991 and references therein). The discovery of coesite in the Monts du Lyonnais area that typifies UHP metamorphism (Lardeaux et al., 2001) showed that the rocks may record significantly higher pressure. This was confirmed by recent studies based on the use of thermodynamic modelling (Berger et al., 2010; Lotout et al., 2018; Lotout et al., 2020). Despite these advances, the prograde part of the $P-T$ path remains unknown and the dynamic of the subduction is therefore largely unconstrained.

The prograde part of a $P-T$ path may be recorded by the chemical zoning of crystals grown during the prograde metamorphism, typically garnet, as well as their inclusion patterns (e.g. Thompson et al., 1977; Spear et al., 1984; Carlson and Schwarze, 1997; Štípská et al., 2006; Tual et al., 2017). Additionally, multi-stage garnet may record a complex crystallization and resorption sequence that can be used to unveil complex $P-T$ paths (e.g. Karabinos, 1984; de Hoÿm de Marien et al., 2019).

One eclogite from the Haut-Allier, sampled at La Borie, was the target of one of the first U-Pb datings of the eclogitefacies metamorphism in the Massif Central (Ducrot et al., 1983) and the obtained Silurian age of c. 430 Ma had a great influence on a number of geodynamic interpretations of the Variscan evolution of the Massif Central. The method used (dissolution of a zircon population) is now known to yield erroneous results (Paquette et al., 2017; Lotout et al., 2018) and our work in progress aims at determining the age of the eclogite-facies metamorphism in this locality with modern methods. Our focus on this locality for specifying with precision the metamorphic evolution of the eclogite was guided by both the historical importance and the position of the eclogite in the Variscan nappe-stack of the EMC. In this contribution, we present the results of a petrologic study using $P-T$ pseudosections in order to constrain the $P-T$ path of a Variscan eclogite sample of the Haut-Allier region in the Massif Central. We take advantage of complex growth/ resorption sequence of porphyroblasts (e.g. garnet, omphacite and amphibole) to decipher rarely identified prograde evolution showing a pressure and temperature increase before an isobaric heating of about $150^{\circ} \mathrm{C}$ at peak pressure conditions.

\section{Geological setting}

The formation of the Variscan belt in western Europe results from the amalgamation of several continental blocks during the convergence of Laurussia and Gondwana in the
Palaeozoic (Matte, 1986; Kroner and Romer, 2013; Stampfli et al., 2013), which led to the formation of Pangea. The French Massif Central belongs to the internal zones of the orogen (e.g. Lardeaux, 2014) and is recognized as a nappe stack of different crustal units (e.g. Burg and Matte, 1978; Burg et al., 1984; Ledru et al., 1989; Faure et al., 2009). However, the Western and the Eastern Massif Central (EMC), located on either side of the lithospheric-scale "Sillon Houiller" fault (Burg et al., 1990) show significant differences. Several eclogite-bearing units are recognized in the Western Massif Central (Girardeau et al., 1986), while only one has been reported from the EMC (Burg and Matte, 1978; Burg et al., 1984). Available petrological and geochronological data on the eclogites from the EMC are equivocal, and their tectonic setting is a matter of debate.

\subsection{Petrological and chronological framework}

Most of the eclogites occur as lenses in the so-called Leptyno-Amphibolite Complex (LAC) (e.g. Santallier et al., 1988), interpreted as a tectonic melange of mafic (amphibolite, gabbros), ultramafic (garnet peridotites), felsic (granitoid orthogneisses, commonly fine-grained, called leptynites) and metasedimentary rocks (e.g. Forestier, 1961; Forestier and Lasnier, 1969; Forestier et al., 1973; Lasnier, 1977; Gardien et al., 1988, 1990). The LAC in the EMC has been variably interpreted in terms of 1) a dismembered continental passive margin, 2) ocean floor tholeiites or 3) a back-arc basin (Piboule, 1977; Giraud et al., 1984; Piboule and Briand, 1985; Bodinier et al., 1988; Briand et al., 1988; Lardeaux, 2014). Regardless of the setting of the protoliths, the LAC is interpreted as a marker of subduction (e.g. Santallier et al., 1988; Ledru et al., 1989; Lardeaux, 2014).

The eclogites from the EMC record a HP, eclogite-facies metamorphism and a subsequent retrogression in the HT amphibolite or granulite facies (e.g. Mercier et al., 1991). Recent petrological works improved the estimation of peak $P$ $T$ conditions with estimations between $15-20 \mathrm{kbar}$ at $\sim 600^{\circ} \mathrm{C}$ in the Najac area (Lotout et al., 2018) and $18-23 \mathrm{kbar}$ at $\sim 750^{\circ} \mathrm{C}$ in the Lévézou massif (Lotout et al., 2020). Coesite in the Monts du Lyonnais typifies UHP conditions of $>28 \mathrm{kbar}$ at $\sim 750^{\circ} \mathrm{C}$ (Lardeaux et al., 2001). Subsequent decompression down to $8-10 \mathrm{kbar}$ is inferred isothermal in the Monts du Lyonnais (Lardeaux et al., 2001) or associated with moderate cooling in the Lévézou $\left(600{ }^{\circ} \mathrm{C}\right.$; Lotout et al., 2020). The eclogites from the LAC thus indicate (U)HP metamorphism and subsequent exhumation at high temperature.

The age of the high-pressure event in the LAC, and thus the subduction event, is not well known. Data suggesting an earlyVariscan, Silurian age (Pin and Lancelot, 1982; Ducrot et al., 1983; Paquette et al., 1995) have been discredited because of the methods used (dissolution of zircon population; Paquette et al., 2017; Lotout et al., 2018). Rare recent works suggest a younger, Devonian age for the eclogite-facies metamorphism in the southern EMC (c. 380 Ma for Najac - Lotout et al., 2018; c. $360 \mathrm{Ma}$ in the Lévézou; Lotout et al., 2020), compatible with ages from other parts of the Variscan belt (Lotout et al., 2018).

\subsection{The Haut-Allier}

The Haut-Allier (HA) belongs to the core of the EMC, where Variscan high-grade metamorphic rocks are exposed. 


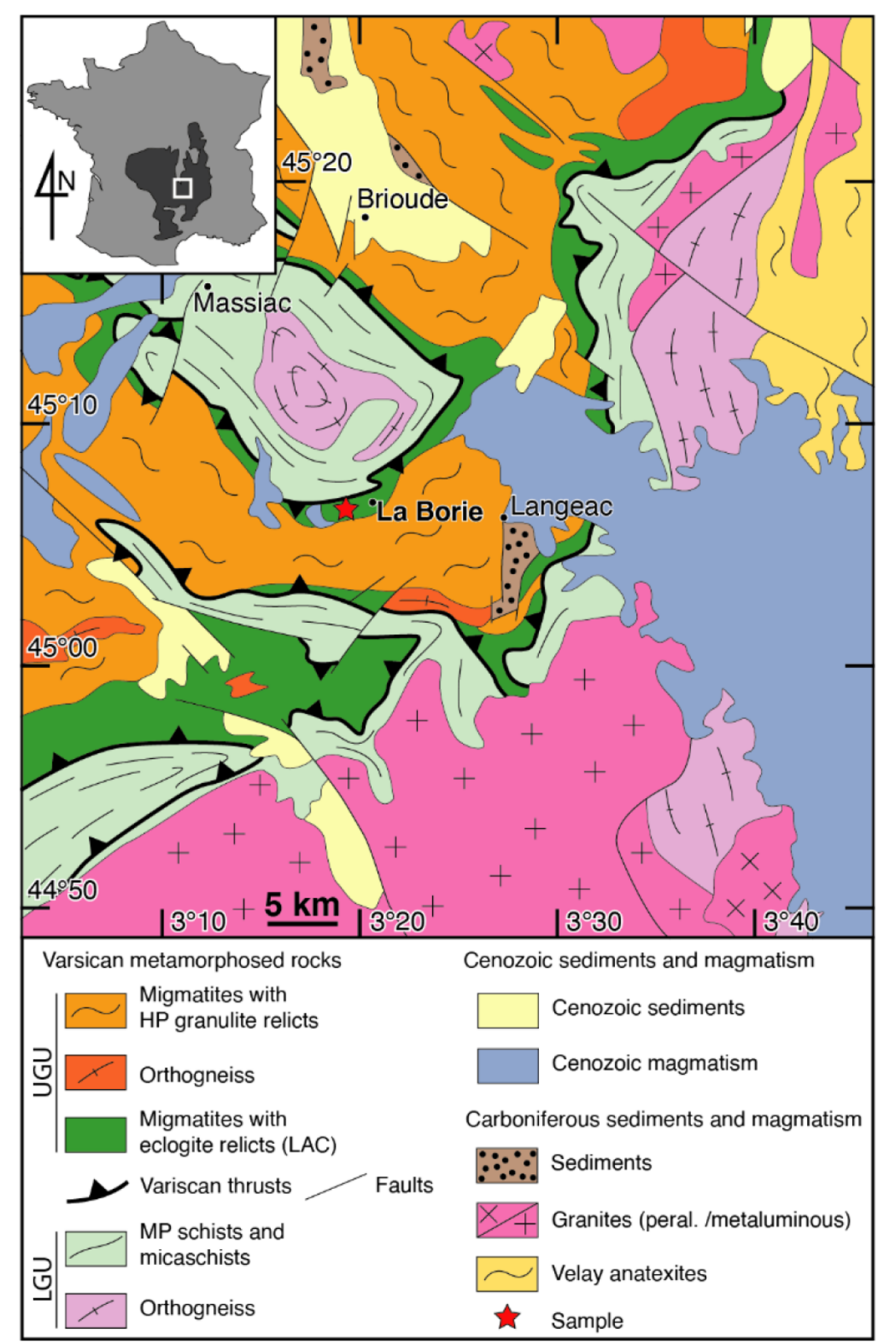

Fig. 1. Geological map and location of the study area in the framework of the French Massif Central (inset; dark grey). The described eclogite has been sampled west of la Borie, in the LAC (456’45.29"N; 319'55.83"E; WGS84).

These rocks were intruded by Carboniferous granitoids (ca. 340 to $310 \mathrm{Ma}$; Gardien et al., 2011; Laurent et al., 2017) and subsequently overlain by Upper Carboniferous sediments as well as by Cainozoic sediments and lavas (Fig. 1). The highgrade rocks are subdivided into two superposed units, the Lower Gneiss Unit (LGU) and the Upper Gneiss Unit (UGU). In the studied area, the LGU is mostly composed of orthogneisses as well as biotite-sillimanite and staurolitekyanite micaschists that record a prograde MP metamorphism. The LGU underwent a heterogeneous partial melting. The UGU is composed of metapelitic biotite-sillimanite(-cordierite) migmatites hosting remnants of kyanite-bearing granulite lenses, metabasites (garnet-pyroxene granulites, amphibolites) and orthogneisses (Forestier and Lasnier, 1969; Marchand, 1974; Lasnier, 1977). The LAC in the HA was defined as the lowermost part of the UGU (Forestier, 1961). The LAC is composed of anatectic biotite-sillimanite micaschists associated with marbles, felsic orthogneiss, metabasites (eclogites, granulites, amphibolites and coronitic gabbros) and ultramafics (garnet peridotites) (Forestier and Lasnier, 1969;
Lasnier, 1968, 1977; Forestier et al., 1973). The superposition of the UGU over the LGU is interpreted as the result of crustal nappe stacking during the exhumation of the UGU (e.g. Burg and Matte, 1978).

Although crustal nappe stacking can occur in different contexts (e.g. Vanderhaeghe, 2012), crustal nappe stacking during continental collision is typically associated with a medium-pressure metamorphism (e.g. England and Thompson, 1984; Le Fort, 1986; Spear, 1993; Jamieson et al., 1998). Surprisingly, available conventional thermobarometry data on the biotite-sillimanite micaschists and the staurolite-kyanite micaschists from the LGU as well as the kyanite-bearing granulites from the UGU indicate peak pressure conditions of $\sim 13 \mathrm{kbar}$ at $700^{\circ} \mathrm{C}$ for both units (Schulz et al., 1996; Schulz, 2014). Prograde metamorphism and partial melting of the LGU, inferred to be coeval with the decompression and melting of the UGU, is interpreted in terms of inverted metamorphism during thrusting (Burg et al., 1984). A $360 \mathrm{Ma}$ age for the crustal nappe stacking is inferred from two EPMA U-Th- $\mathrm{Pb}$ studies on monazite in an UGU granulite (Gardien et al., 2011; Schulz, 2014). The kyanite-bearing granulite from the UGU underwent a polystage decompression, typified by the replacement of kyanite by sillimanite (Marchand, 1974) either associated with cooling or heating with peak temperature close to $700-800{ }^{\circ} \mathrm{C}$ between $5-$ $10 \mathrm{kbar}$ ( Gardien et al., 2011; Schulz, 2014). A late heating is also possibly recorded in metabasites from the LAC (Nicollet et al., 1993). The decompression is constrained between ca. $330 \mathrm{Ma}$ by U-Th-Pb on monazite from the granulite (Schulz, 2014 ) and ca. $315 \mathrm{Ma}$ by U-Pb on zircon from $\mathrm{S} / \mathrm{C}$ granites (Gardien et al., 2011). Subsequent cooling is estimated at ca. $275 \mathrm{Ma}$ by ${ }^{40} \mathrm{Ar} /{ }^{39} \mathrm{Ar}$ on K-feldspar (Gardien et al., 2011).

Nappe stacking was preceded by an earlier subduction event recorded by granulite- and eclogite-facies metamorphism in metabasites from the LAC (Matte and Burg, 1981). The metabasites in the HA share geochemical affinities with either ocean-floor tholeiites or back-arc basalts (Giraud et al., 1984). Conventional thermobarometry applied on the HA garnet-pyroxene granulites resulted in peak $P-T$ conditions of about $20 \mathrm{kbar}$ for a temperature fixed at $800^{\circ} \mathrm{C}$ (Pin and Vielzeuf, 1988) and the $P-T$ evolution of the eclogites was never studied in detail. The age of this eclogite facies metamorphism has been estimated at ca. $430 \mathrm{Ma}$ by $\mathrm{U} / \mathrm{Pb}$ on dissolved zircon population (Ducrot et al., 1983), but this method is known to yield erroneous results (Paquette et al., 2017) and the age of the eclogite-facies metamorphism must be determined with modern methods.

\section{Petrography and mineral chemistry}

Mineral analyses have been performed with a Cameca SX100 electron microprobe (Microsonde Ouest, IFREMER, Brest-Plouzané, France). Representative analyses of selected minerals are listed in Supplementary material (Tab. S1). The mineral abbreviations are consistent with Holland and Powell (2011) and Green et al. (2016) - amp: amphibole, bi: biotite, chl: chlorite, cpx: clinopyroxene, coe: coesite, ep: epidote, g: garnet, ilm: ilmenite, ksp: potassium feldspar, ky: kyanite, law: lawsonite, mu: muscovite, opx: orthopyroxene, pl: plagioclase, q: quartz, ru: rutile, sph: sphene (titanite), sp: spinel, sul: 


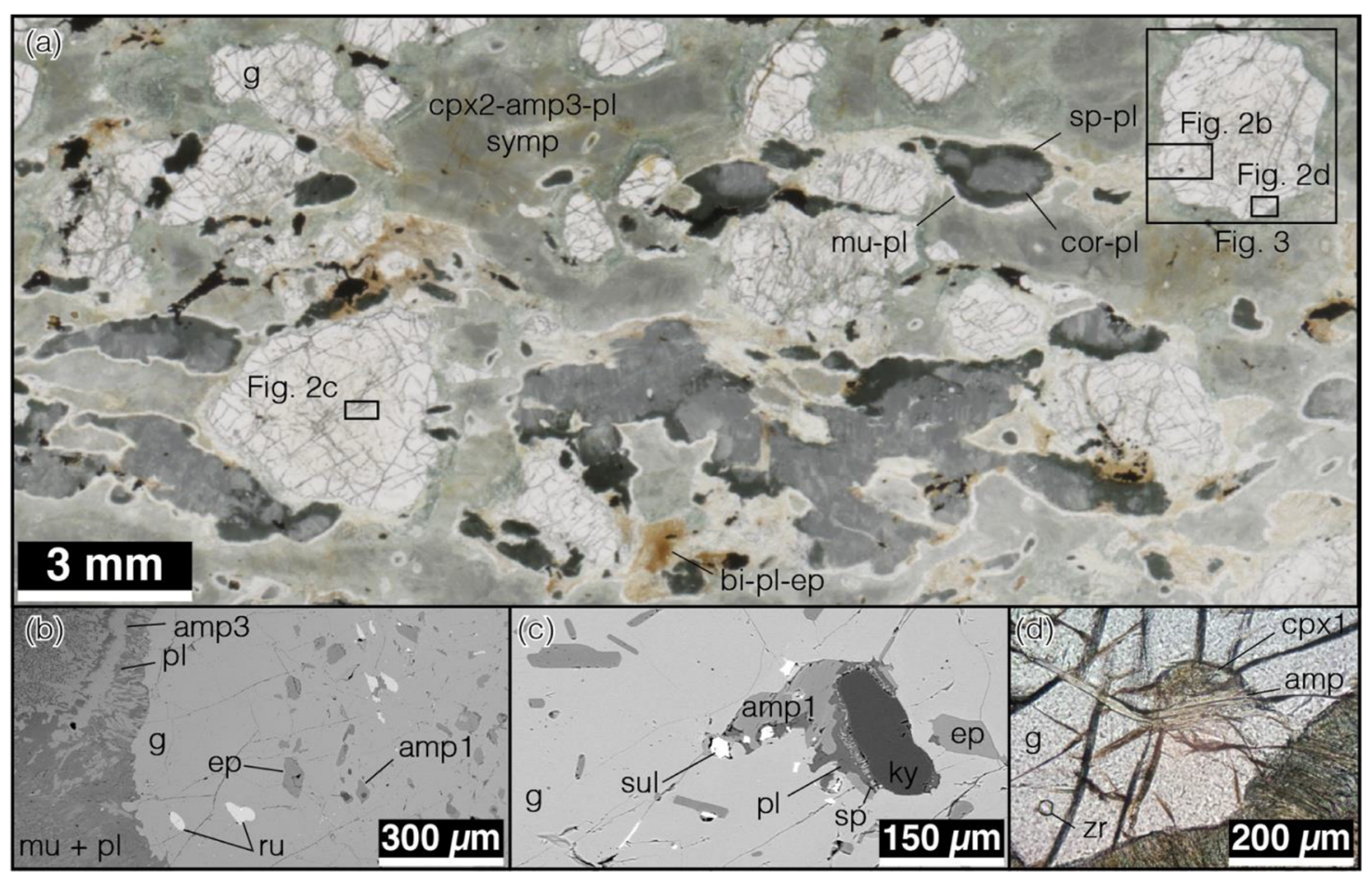

Fig. 2. Microtextural features. Photomicrographs (plane polarized light, PPL) and BSE images of a part of the thin section of the studied sample (a) and details of inclusions in garnet (b, c, d). (a) Garnet crystals in a matrix composed of various symplectites (symp), the shape of which marks a fabric. Yet, the fine aggregates forming these symplectites are undeformed (PPL). (b) Multiple inclusions of amphibole (amp1) and epidote in garnet mantle, and inclusion-poor rim. Garnet displays irregular edges, is in contact with muscovite-plagioclase symplectite, and is rimmed by a corona of amphibole (amp3) and plagioclase (BSE image). (c) Inclusions of epidote, amphibole (amp1), sulphide (sul) and kyanite in garnet. Kyanite is surrounded by a corona of spinel and plagioclase (BSE image). (d) Inclusion of omphacite (cpx1) in garnet2 displays an irregular edge (upper side of the crystal).

sulphide. Mineral endmembers (expressed in mole \%) and compositional variables (mole fractions) are: $X_{\mathrm{Mg}}=\mathrm{Mg} /(\mathrm{Mg}$ $+\mathrm{Fe}) ; \mathrm{X}_{\mathrm{F} 3}=\mathrm{Fe}^{3+} /\left(\mathrm{Fe}^{3+}+\mathrm{Fe}^{2+}\right)$; almandine, alm $=\mathrm{Fe} /(\mathrm{Fe}$ $+\mathrm{Mg}+\mathrm{Ca}+\mathrm{Mn})$, pyrope, $\mathrm{prp}=\mathrm{Mg} /(\mathrm{Fe}+\mathrm{Mg}+\mathrm{Ca}+\mathrm{Mn})$, grossular, grs $=\mathrm{Ca} /(\mathrm{Fe}+\mathrm{Mg}+\mathrm{Ca}+\mathrm{Mn})$, spessartine, $\mathrm{sps}=$ $\mathrm{Mn} /(\mathrm{Fe}+\mathrm{Mg}+\mathrm{Ca}+\mathrm{Mn}) ;$ jadeite, $\mathrm{jd}=\mathrm{Na} /(\mathrm{Na}+\mathrm{Ca}) ;$ albite, $\mathrm{ab}=\mathrm{Na} /(\mathrm{Ca}+\mathrm{Na}+\mathrm{K})$, anorthite, $\quad$ an $=\mathrm{Ca} /(\mathrm{Ca}+\mathrm{Na}+\mathrm{K})$; orthoclase, or $=\mathrm{K} /(\mathrm{Ca}+\mathrm{Na}+\mathrm{K})$; pistacite, $\mathrm{ps}=\mathrm{Fe}^{3+} /\left(\mathrm{Fe}^{3+}\right.$ $+\mathrm{Al}-2) ;$ geikielite, $\mathrm{gk}=\mathrm{Mg} /\left(\mathrm{Fe}^{2+}+\mathrm{Fe}^{3+}+\mathrm{Mg}+\mathrm{Mn}\right)$; pfu: per formula unit. In addition, the amount of calcium on site $\mathrm{B}$ labelled $\mathrm{Ca}(\mathrm{B})$ and $\mathrm{Na}$ on site $\mathrm{A}$ labelled $\mathrm{Na}(\mathrm{A})$ in amphibole have been estimated following the procedure of Leake et al. (1997).

The studied eclogite was sampled west of the historical locality of La Borie (Fig. 1), from a hectometre lens of variously retrogressed eclogites surrounded by diatexites, in the lowermost part of the LAC. Under the microscope, the studied sample is a retrogressed eclogite composed of garnet porphyroblasts (up to $3 \mathrm{~mm}$ ) and various fine-grained $(<25 \mu \mathrm{m})$ symplectites (Fig. 2a). It also contains minor rutile, ilmenite, sulphide, apatite and zircon. A fabric is marked by the ellipsoidal shape of the symplectites (Fig. 2a). The crystals that compose these aggregates are randomly oriented and lack signs of deformation, which suggests static replacement of primary crystals that had a preferred orientation.
Garnet contains abundant inclusions of amphibole, epidote, rutile, quartz as well as minor kyanite, clinopyroxene (Figs. $2 \mathrm{~b}-2 \mathrm{~d}$ ), phengitic muscovite (mu1; $\mathrm{Si}=3.7 \mathrm{pfu} ; \mathrm{X}_{\mathrm{Mg}}=$ $0.6)$ and zircon. The distribution of the inclusions defines an optical zoning (Figs. 3a and 3b). Garnet core and mantle contain numerous inclusions of epidote $(\mathrm{ep} 1 ; \mathrm{ps}=0-40)$ and pargasitic amphibole $(\mathrm{amp} 1 ; \mathrm{Ca}(\mathrm{B})=1.5-1.8 ; \mathrm{Na}(\mathrm{A})=0.4$ $\left.0.6 ; \mathrm{Al}=2.7-3.1 \mathrm{pfu} ; \mathrm{Si}=6.0-6.1 \mathrm{pfu} ; \mathrm{X}_{\mathrm{Mg}}=0.64-0.71\right)$. They are small $(<100 \mu \mathrm{m})$ in the core and significantly larger (up to $200 \mu \mathrm{m}$ ) in the mantle. Garnet rim is free of epidote and contains only scarce, more aluminous amphibole $(\mathrm{Al}=3.5$ $3.6 \mathrm{pfu} ; \mathrm{X}_{\mathrm{Mg}}=0.62-0.66$ ) as well as rutile and zircon. Garnet core, mantle and rim are referred to as garnet1 (see below). An outer rim, referred to as garnet2, is characterized by the presence of more magnesian amphibole (Fig. 3a; amp2; $\left.\mathrm{Al}=3.2-3.5 \mathrm{pfu} ; \mathrm{X}_{\mathrm{Mg}}=0.76-0.82\right)$ and anhedral omphacitic clinopyroxene (Fig. 2d; cpx1; $\mathrm{Al}=0.42 \mathrm{pfu} ; \mathrm{X}_{\mathrm{Mg}}=0.85-0.90$ ).

The optical zoning of garnet defined by the inclusion pattern coincides with the chemical zoning (Fig. 3). Garnetl is characterized by a decreasing grossular content and increasing pyrope content. The zoning is weak in the core with a roughly constant grossular (grs28-30) and spessartine (sps2) contents, slightly increasing pyrope (prp21 $\rightarrow 23$ ) and decreasing almandine content (alm47 $\rightarrow 45$ ). The mantle and the rim are characterized by a stronger zoning that involves further increase of pyrope (prp23 $\rightarrow 38 \rightarrow 40$ ) associated with a 

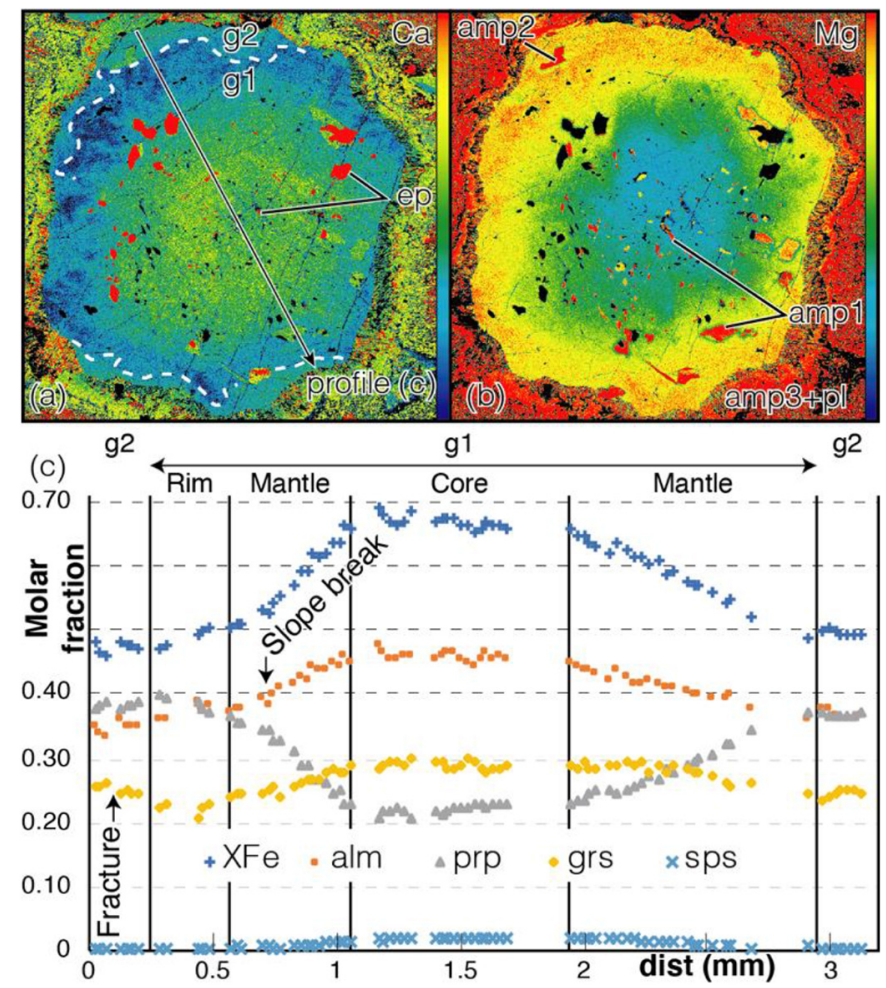

Fig. 3. Inclusion pattern and chemical zoning of garnet. X-ray maps for (a) $\mathrm{Mg}$ and (b) Ca contents in garnet. Notice the change of size and amount of inclusions from garnet core, mantle and rim. (c) Chemical zoning profile in garnet (location marked by black arrow in a).

decrease of the almandine (alm $41 \rightarrow 38 \rightarrow 36$ ), grossular (grs28$30 \rightarrow 23 \rightarrow 21)$ and spessartine (sps $\rightarrow 1 \rightarrow 1$ ) contents. The highest proportion of pyrope corresponds to the lowest grossular content. It is noteworthy that the slope of the pyrope, grossular and almandine zoning flattens from the outer part of the mantle rimward (transition marked by an arrow in Fig. 3c). The outer rim (garnet2) displays a striking inversion of the zoning trend of grossular $(\mathrm{grs} 21 \rightarrow 26)$ and pyrope (prp40 $\rightarrow 39$ ). The discontinuity of the grossular content corresponds to an irregular boundary that marks the limit between garnet1 and garnet2 (Fig. 3a).

Garnet is surrounded by a corona of amphibole and plagioclase symplectite, the composition of which is similar to the composition of amphibole and plagioclase of other symplectites in the matrix. The most abundant type of matrix symplectites comprises diopside $\left(\mathrm{cpx} 2 ; \mathrm{Al}=0-0.1 \mathrm{pfu} ; \mathrm{X}_{\mathrm{Mg}}=\right.$ 0.85-0.86), amphibole (amp3; pargasite to magnesiohornblende, $\mathrm{Ca}(\mathrm{B})=1.7-1.9 ; \mathrm{Na}(\mathrm{A})=0.2-0.6 ; \mathrm{Al}=3.2-3.5 ; \mathrm{Si}=$ $\left.6.0-7.2 \mathrm{pfu} ; \mathrm{X}_{\mathrm{Mg}}=0.75-0.88\right)$, plagioclase $(\mathrm{an}=18-35)$, and minor quartz (Fig. 2a). Another type of symplectites is distinctly Al-rich and coronitic. Corundum is present in the inner corona, followed rimward by spinel $\left(\mathrm{X}_{\mathrm{Mg}}=0.44-0.52\right)$ and muscovite $(\mathrm{Si}=3.1 \mathrm{pfu})$. These minerals are intergrown with plagioclase of a strongly variable composition from anorthite-rich in the inner symplectite to albite-rich in the rim $(\mathrm{an}=91 \rightarrow 20)$. Anhedral kyanite is locally observed in the core of these coronitic structures. The third type of symplectite is $\mathrm{K}$ rich and contains biotite, muscovite $(\mathrm{Si}=3.0-3.1 \mathrm{pfu})$ associated with plagioclase (an18-82) and minor epidote (ps0). This

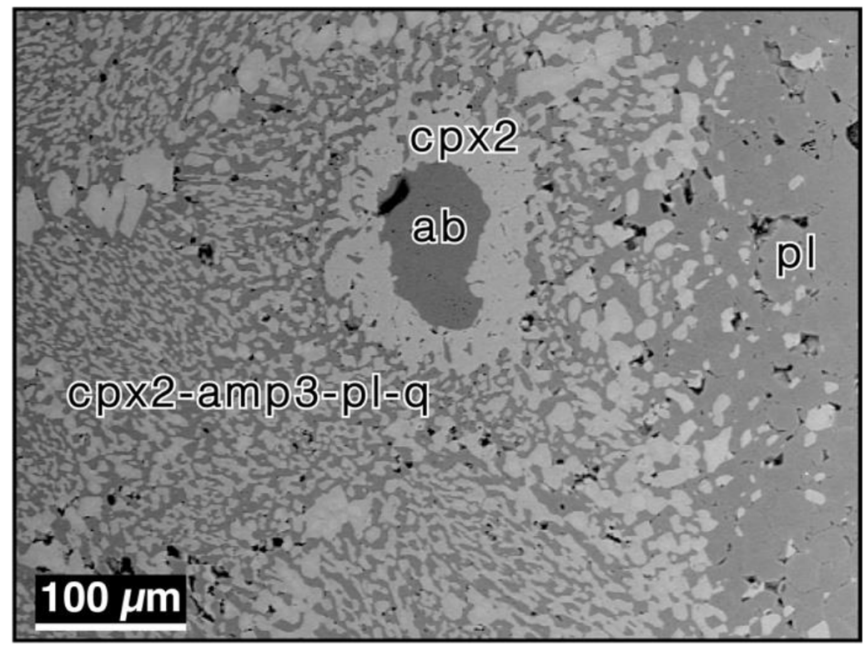

Fig. 4. BSE image of an anhedral albite bleb surrounded by a corona of diopside (cpx2) in contact with the symplectites in the matrix.

type of symplectites is associated with anhedral rutile juxtaposed to ilmenite (geikielite up to $19 \%$, pyrophannite $<1 \%$ ), both of them being locally surrounded by a corona of sphene.

A key petrographic feature for the understanding of the sample are plagioclase crystals found as anhedral blebs of pure albite $(100 \mu \mathrm{m})$ in the matrix (Fig. 4). The crystals are significantly smaller than garnet1 (mm-sized) but one to two orders of magnitude larger than crystals forming symplectites $(1-10 \mu \mathrm{m})$. Additionally, the albite blebs are systematically isolated from the matrix symplectites by a corona of diopside. These observations suggest that the albite blebs belong to an intermediate stage of metamorphism, between the crystallization of the primary coarse-grained garnet-bearing assemblage and the retrogression of the sample associated with the development of the symplectites.

\section{Interpretation of the petrographic observations}

These observations are interpreted in terms of three metamorphic stages. The M1 assemblage is defined by coarse (mm-sized) garnet, its inclusion suite and the initial nature of the matrix crystals subsequently replaced by symplectites during M3. An intermediate M2 stage is subtle and characterized, among others, by small porphyroblasts of albite, and garnet2 overgrowths over garnet1.

The dominant M1 assemblage comprises garnet and three minerals now replaced by different symplectites. Diopsideamphibole-plagioclase-quartz symplectites are interpreted to replace omphacite, corundum/spinel-plagioclase (Al-rich) symplectites as former kyanite, and biotite-bearing symplectites as replacing a K-rich mineral, probably muscovite. This interpretation is strengthened by inclusions of omphacite, kyanite and muscovite in garnet. In addition, garnet also contains rutile and quartz as well as epidote and amphibole in its core. The garnet + omphacite-bearing but plagioclase-free assemblage M1 (garnet-omphacite-kyanite-muscovite-rutile-quartz with 
epidote-amphibole in the core of garnet) typifies eclogite-facies conditions. In detail, the chemical and textural zoning of garnet marked by a decrease of spessartine and increase of pyrope as well as the disappearance of epidote and amphibole in garnet rim (g1, Fig. 3a) suggest that the M1 metamorphic event corresponds to a prograde evolution of the $P-T$ conditions.

The irregular boundary between the rim $(\mathrm{g} 1)$ and the outer rim of garnet (g2, Fig. 3a), is associated with the relatively abrupt increase of grossular, as well as the irregular garnet1 contour, commonly with convex faces, cutting across the concentric growth zoning. This suggests a period of partial resorption of garnet1, grown during $\mathrm{M} 1$, before the crystallization of garnet2 (outer rim-g2) during M2. M2 is also marked by the renewed growth of euhedral amphibole2 and by the resorption of omphacite, both preserved as inclusions in garnet2. Minor rutile and quartz, preserved as inclusions in garnet2, were also part of the assemblage. The albite blebs found in the matrix are inferred to belong to the M2 stage because 1) their grain-size $(100 \mu \mathrm{m})$ is an order of magnitude smaller than the grain-size of the M1 assemblage (mm-sized) and 2) they are anhedral and isolated from the matrix symplectites grown during M3 by a corona of diopside $(1-10 \mu \mathrm{m})$. These observations suggest that albite neither belongs to the M1 assemblage nor to the M3 symplectites but to an intermediate stage, M2. The equilibrium with clinopyroxene is suggested by the inclusion of omphacite (albeit anhedral) in garnet2. The M2 assemblage contains at least garnet2-albite-amphibole2-rutile-quartz and probably omphacite in addition to a possible K-bearing mineral and/ or kyanite.

The M3 event is characterized by the partial or complete replacement of the large M1 crystals by plagioclase-, amphibole-, diopside- and/or corundum-/spinel-bearing symplectites. Such symplectites typically develop during decompression of high-pressure rocks, suggesting that M3 occurred at lower pressures. This agrees with the observed relations between rutile, ilmenite and sphene that suggest a sequential growth typically observed in similar rocks at decreasing pressure (e.g. Zhang et al., 1995).

\section{Phase diagram modelling}

$P-T$ pseudosections were calculated in the model system MnNCKFMASHTO and NCFMASHO using Theriak/Domino v. 2015 (de Capitani and Brown, 1987; de Capitani and Petrakakis, 2010) and the thermodynamic data set 6.2 (Holland and Powell, 2011). The solution phases considered in the calculations and the activity-composition models used are amphibole, clinopyroxene, melt (Green et al., 2016); biotite, chlorite, garnet, muscovite (White et al., 2014b); epidote (Holland and Powell, 2011); ilmenite (White et al., 2000; White et al., 2014b); orthopyroxene (White et al., 2014a, b); plagioclase (Holland and Powell, 2003); spinel (White et al., 2002). The mixing models were converted for Theriak/ Domino by Doug Tinkham (http://dtinkham.net/peq.html).

Bulk compositions used for the calculations were obtained by the area-scan method at SEM-EDS (JSM-7100 F scanning electron microscope, CMEBA, University Rennes 1) on parts of thin sections estimated to approach an equilibration volume, and the results were checked for robustness. $\mathrm{FeO}\left(\right.$ vs. $\left.\mathrm{Fe}_{2} \mathrm{O}_{3}\right)$ was set so that the $\mathrm{FeO} / \mathrm{Fe}_{2} \mathrm{O}_{3}$ ratio was equal to that of the bulk rock composition (analysed at the Geochemical and Petrographical Research Center, SARM laboratory, CNRS-CRPG, Nancy; FeO measured by wet titration) unless otherwise stated. The bulk compositions used are indicated as insets in the diagrams in mole per cent normalized to $100 \%$ with the exception of $\mathrm{H}_{2} \mathrm{O}$ which is indicated as an additional component.

A first $P-T$ pseudosection (Fig. 5) was computed in order to investigate the initial prograde metamorphism. This computation was achieved using a bulk composition measured on an area of a thin section comprising garnet with inclusions of epidote, amphibole, omphacite and a proportion of matrix with diopside-amphibole-plagioclase bearing symplectite, Alrich symplectite, K-rich symplectite and albite blebs. The $P-T$ pseudosection was contoured with compositional isopleths for garnet and amphibole. In this diagram, epidote is stable below $20-24.5 \mathrm{kbar}$ and $750{ }^{\circ} \mathrm{C}$. Isopleths corresponding to the composition of garnet core (alm47; prp23; grs28) and the lowest observed $\mathrm{Al}$ content in amphibole $(\mathrm{Al}=2.7 \mathrm{pfu})$ intersect in the field cpx-amp-g-ep-mu-q-ru around $650^{\circ} \mathrm{C}$ and $20 \mathrm{kbar}$. Decreasing grossular and almandine content together with an increasing pyrope content is compatible with increasing $P-T$ conditions toward the stability field of kyanite and ultimately the epidote-absent field (cpx-amp-g-mu-ky-q$\mathrm{ru}$ ). This field is limited at higher pressures by the amphiboleout line between $650{ }^{\circ} \mathrm{C}$ at $28 \mathrm{kbar}$ and $750{ }^{\circ} \mathrm{C}$ at $23 \mathrm{kbar}$. The flattening of the slope (in the chemical zoning profile, Fig. 3) of pyrope, almandine and grossular content in the outer mantle of garnet suggests that garnet continued to crystallize, but its composition evolved less rapidly. In the pseudosection this corresponds to a $P-T$ evolution that crosses the compositional isopleths at lower angle. A curvature of the $P-T$ path from crossing the isopleths initially at high angle to lower angle afterward indicates a roughly isobaric heating in the field cpxamp-g-mu-ky-q-ru-fluid. This interpretation was checked for robustness by modelling the expected garnet zoning along a $P$ $T$ path without curvature (i.e. straight from $650^{\circ} \mathrm{C}, 20 \mathrm{kbar}$ to $750{ }^{\circ} \mathrm{C}, 22.5 \mathrm{kbar}$ ) and a $P-T$ path first dominated by a pressure and temperature increase (from $650{ }^{\circ} \mathrm{C}, 20 \mathrm{kbar}$ to $700{ }^{\circ} \mathrm{C}$, $22.5 \mathrm{kbar}$ ), and then by isobaric heating up to $750^{\circ} \mathrm{C}$ (see Supplementary Material Fig. S1 for details). Compositional isopleths for garnet1 rim (alm36; prp40; grs21) intersect in the field cpx-amp-g-mu-ky-q-ru, close to the melt-in line around $22.5 \mathrm{kbar}$ and $750{ }^{\circ} \mathrm{C}$.

Lower pyrope and almandine as well as higher grossular contents suggest that garnet 2 must have crystallized in the $P-T$ domain where melt is stable (Fig. 5). Since melt incorporates a significant amount of $\mathrm{H}_{2} \mathrm{O}$, and the topology of the pseudosection beyond the solidus is expected to be dependent of the availability of water, another $P-T$ pseudosection has been computed to investigate the evolution of the rock in the melt-present region (Fig. 6). Except for the $\mathrm{H}_{2} \mathrm{O}$ content, the $P-T$ pseudosection has been computed using the same bulk rock composition (this aspect is briefly discussed below).

The second $P-T$ pseudosection (Fig. 6) is used to infer the $P-T$ conditions of the $\mathrm{M} 2$ metamorphism. The amount of $\mathrm{H}_{2} \mathrm{O}$ is set so that the rock is just $\mathrm{H}_{2} \mathrm{O}$-saturated at $750{ }^{\circ} \mathrm{C}$ and $22.5 \mathrm{kbar}$, in the field cpx-amp-g-mu-ky-q-ru (i.e. contains about 1 volume $\%$ of free aqueous fluid accounting for interstitial space filled with fluids, as a result of progressive 


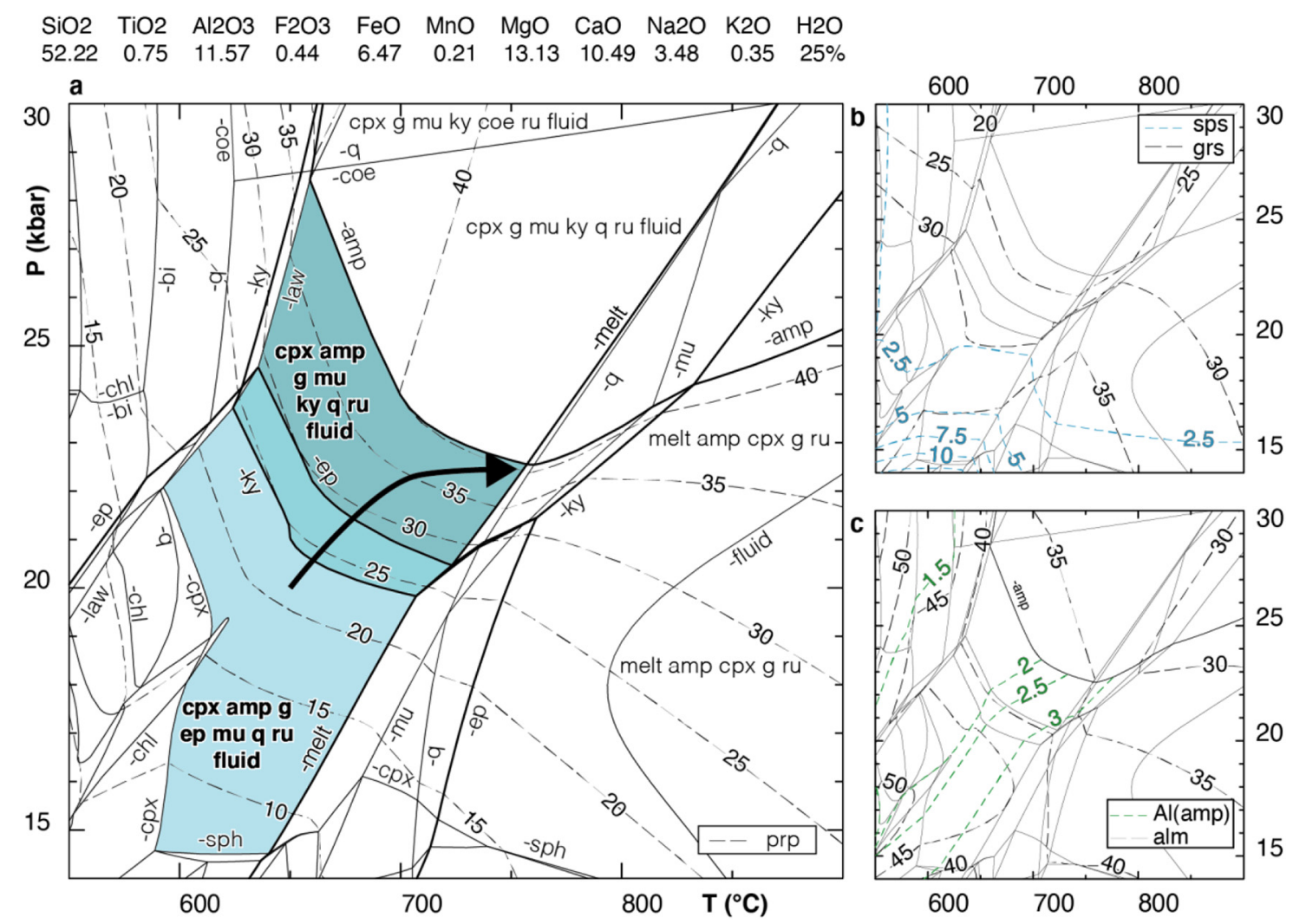

Fig. 5. $P-T$ pseudosection and selected compositional isopleths calculated in the model system MnNCKFMASHTO for a local bulk composition of a part of the sample measured by SEM. Coloured fields highlight the stability of the M1 assemblage with epidote, epidote-kyanite and kyanite. The arbitrary large amount of $\mathrm{H}_{2} \mathrm{O}$ ensures that all the subsolidus assemblages are saturated in aqueous fluid.

dehydration-dominated subsolidus metamorphism). Calculated compositional isopleths corresponding to the composition of garnet2 (alm36; prp38; grs26) intersect in the field meltamp-cpx-g-pl-ky-q-ru-mu/ksp between $850-900^{\circ} \mathrm{C}$ and $18.5-$ $19.5 \mathrm{kbar}$ in agreement with the inferred assemblage (garnet2albite-amphibole-rutile-quartz-clinopyroxene \pm kyanite $\pm \mathrm{K}$ -

bearing mineral). The composition of amphibole2 $(\mathrm{Al}=3.2-$ $3.5 \mathrm{pfu}$ ) is coherent with this estimation, but does not allow to better constrain the $P-T$ conditions. The resorption of garnet1 and crystallization of garnet 2 is a first order constraint to interpret this $P-T$ pseudosection. Indeed, a straight $P-T$ path between the $\mathrm{M} 1$ peak conditions $\left(750^{\circ} \mathrm{C}\right.$ and $\left.22.5 \mathrm{kbar}\right)$ and the $\mathrm{M} 2$ conditions (ca. $875^{\circ} \mathrm{C}$ and $19.5 \mathrm{kbar}$ ) could not account for the observations since such $P-T$ path would only result in increasing the amount of garnet, therefore, the resorption of the garnet1 would not be observed. However, heating from $22.5 \mathrm{kbar}, 750{ }^{\circ} \mathrm{C}$ would result in garnet mode increase (resulting in additional growth of garnet1) and a subsequent pressure decrease to $\sim 870^{\circ} \mathrm{C}, 19.5 \mathrm{kbar}$ would decrease garnet mode in the field melt-cpx-g-mu-ky-q-ru (accounting for the inferred resorption of garnet1) before a subsequent increase in the plagioclase-bearing field (resulting in the growth of garnet2). Furthermore, the mode of garnet in the melt-ampcpx-g-pl-ky-q-ru-mu/ksp field must be higher than that corresponding to the $P-T$ conditions of the preserved garnet 1 $\operatorname{rim}\left(34 \%\right.$ of garnet at $\left.750^{\circ} \mathrm{C}, 22.5 \mathrm{kbar}\right)$ to account for the growth of garnet2, suggesting that the rock equilibrated at temperature higher than $870{ }^{\circ} \mathrm{C}$, in the field melt-amp-cpx-gpl-ksp-ky-q-ru. Clinopyroxene mode is very pressure-sensitive and expected to decrease with decreasing pressure. This $P-T$ path would then also account for the anhedral shape of clinopyroxene included in garnet2. Furthermore, this $\mathrm{P}-\mathrm{T}$ path would cross the amphibole-in line at $870^{\circ} \mathrm{C}, 20 \mathrm{kbar}$ and account for the renewed growth of amphibole (included in garnet2).

A final pseudosection (Fig. 7) has been calculated in order to investigate the retrograde $P-T$ path and the conditions of the M3 stage using the bulk composition of a small area of symplectite composed of diopside, amphibole, plagioclase and a small amount of quartz, inferred to mostly be the product of retrogression of former $\mathrm{M} 1$ omphacite. The $\mathrm{H}_{2} \mathrm{O}$ amount was arbitrarily fixed as equivalent to the previous $P-T$ pseudosection and the $\mathrm{X}_{\mathrm{F} 3}$ ratio set in agreement with the ferric iron incorporated in omphacite at $19.5 \mathrm{kbar}$ and $875^{\circ} \mathrm{C}\left(\mathrm{X}_{\mathrm{F} 3}=\right.$ 0.40 ). In the resulting diagram, the field corresponding to the observed assemblage (amp-cpx-pl-q) extends from $750{ }^{\circ} \mathrm{C}$ to $875^{\circ} \mathrm{C}$ and $3 \mathrm{kbar}$ to $15 \mathrm{kbar}$. The observed composition range for $\mathrm{Al}$ in amphibole $(\mathrm{Al}=1.1-2.4 \mathrm{pfu})$ from the matrix is consistent with an equilibration pressure below $9 \mathrm{kbar}$ delimiting the temperature range between $750{ }^{\circ} \mathrm{C}$ and $850^{\circ} \mathrm{C}$. Though less constraining, this is also in agreement with the observed $\mathrm{Si}$ content of amphibole $(\mathrm{Si}=6.0-7.2 \mathrm{pfu})$, $\mathrm{Al}$ in clinopyroxene $(\mathrm{Al}=0-0.1 \mathrm{pfu})$ and anorthite content of plagioclase $(\mathrm{an}=18-35)$. 


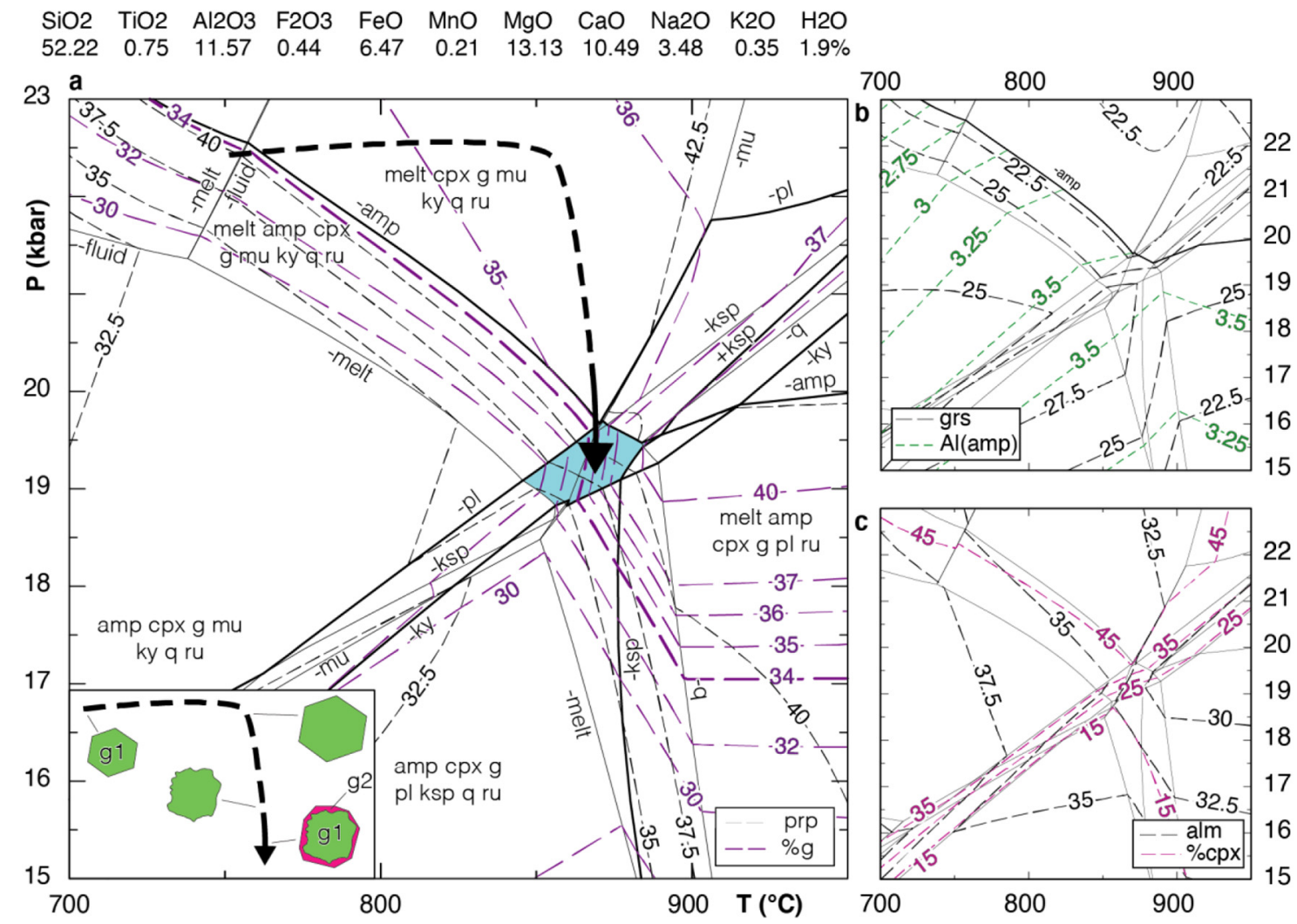

Fig. 6. $P-T$ pseudosection for the same bulk composition as Figure 5, except for a limited amount of $\mathrm{H}_{2} \mathrm{O}$ (see text for details). Note that the scale is different from Figure 5 and that the amount of $\mathrm{H}_{2} \mathrm{O}$ expressed as a molar proportion is equivalent to $\sim 1 \%$ of volume of the rock at $750{ }^{\circ} \mathrm{C}$ and $22.5 \mathrm{kbar}$. The diagram is contoured with modal isopleths for garnet (a) and clinopyroxene (c), and compositional isopleths for pyrope (a), grossular (b), almandine (c), and the aluminium content in amphibole (b). The blue-coloured field corresponds to the inferred M2 assemblage melt-amp-cpx-g-pl-ky-q-ru-mu/ksp. The inferred garnet resorption and crystallization sequence is shown as inset in (a).

\section{Discussion}

\subsection{Considering garnet fractionation}

Although garnet fractionation may affect the $P-T$ pseudosection results (e.g. Zuluaga et al., 2005), this effect on the general pseudosection topology is commonly limited, beyond the garnet-in line. Furthermore, in the sample studied, garnet contains abundant inclusions in the core. These inclusions represent to a certain degree the matrix of the rock. Consequently, the growing garnet did not only fractionate its own composition, but also the composition of the matrix, and the resulting modification of the effective bulk composition of the rock is therefore negligible. A $P-T$ pseudosection using the bulk rock composition with the garnet cores removed (without considering the inclusions) has been calculated, nevertheless, and the interested reader is referred to the Supplementary material for details (Fig. S2).

\subsection{Partial melting and $\mathrm{H}_{2} \mathrm{O}$-content of the rock}

The $P-T$ path determined in this contribution suggests that the studied sample equilibrated above the hydrated solidus. Yet, neither leucosomes nor melt inclusions, also referred to as "nanogranites" in the literature (e.g. Cesare et al., 2009) were observed. Hydrated partial melting may occur in a rock given that such rock contained a free aqueous fluid and reached temperatures high enough to cross the hydrated solidus. In this section we argue that these conditions were fulfilled and point out that the inferred equilibration of the rock above the solidus during M2 offers the advantage to explain several first-order petrographic observations, a posteriori supporting the results of the pseudosections modelling.

In the studied sample, garnet cores contain numerous inclusions of epidote and amphibole, whereas garnet1 rims are strikingly free of such inclusions. Given the dehydrating nature of most prograde metamorphic reactions, the disappearance of epidote and amphibole is interpreted, with the support of $P-T$ pseudosection, in terms of epidote and amphibole breakdown coeval with garnet growth during increasing pressure and temperature at sub-solidus conditions. Epidote and amphibole breakdown released a free aqueous fluid, filling the inter-crystalline space of the rock, even in the improbable case that the rock was not fluidsaturated before. Such space is thought to be equivalent to $1 \%$ of the rock volume (e.g. Thompson and Connolly, 1990). During the prograde M1 stage, the rock reached $P-T$ conditions of at least about $750^{\circ} \mathrm{C}, 22.5 \mathrm{kbar}$ during an isobaric heating, flirting with the modelled hydrated solidus. Therefore, the basic requirement for the studied sample to undergo hydrated melting are satisfied and there are no $a$ priori reasons to exclude this possibility. 


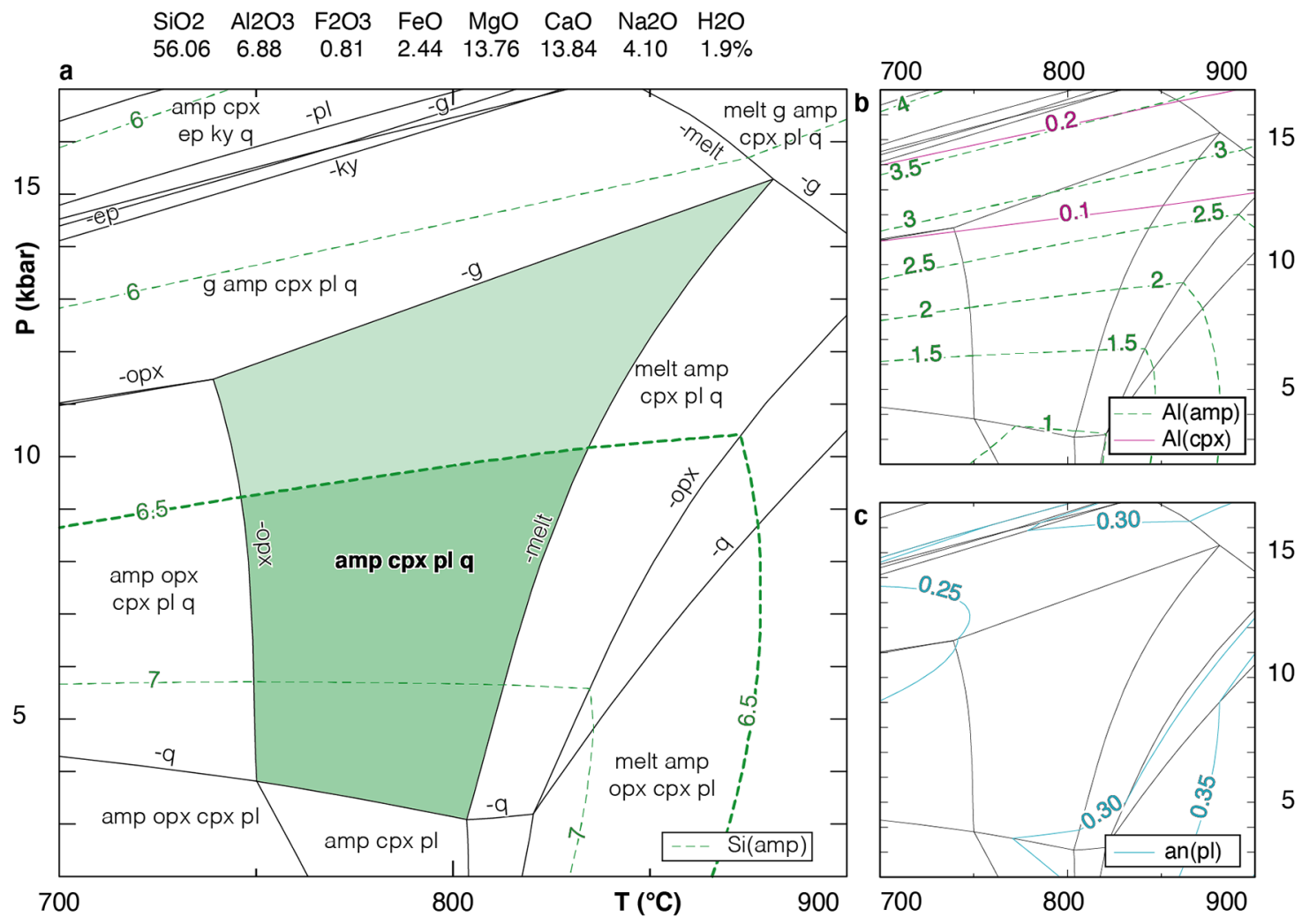

Fig. 7. $P-T$ pseudosection and selected isopleths calculated in the NCFMASHO system for a SEM-measured bulk composition of a part of the amphibole-clinopyroxene-plagioclase-quartz symplectite from the matrix. The diagram is contoured with Si content isopleths for amphibole (a), $\mathrm{Al}$ content isopleths for amphibole and clinopyroxene (b) and compositional isopleths for the anorthite content in plagioclase (c).

The mineral composition of the M2 minerals, in particular garnet2, suggests $P-T$ conditions beyond the hydrated solidus and we explored the possibility that the rock recorded partial melting during M2. Pseudosection modelling for the M2 stage successfully reproduces several first-order petrographic constraints in the melt-present domain such as 1) garnet1 resorption and garnet2 overgrowth, 2) garnet2 composition, 3 ) clinopyroxene resorption, and 4) the renewed growth of amphibole 2. The absence of unquestionable evidence of melt may be explained either by the possibility of melt to flow along strain gradients toward another location, preventing the formation of in-situ leucosomes, by the low proportion of melt produced and by the small probability to observe trapped melt inclusions in the tiny garnet 2 overgrowths. Consequently, despite the absence of direct evidence of partial melting, the general fit between $P-T$ pseudosection modelling, several petrographic observations and mineral compositions, supports the results of the modelling and may be taken as indirect evidence of partial melting of the eclogite at the peak of M1 and during $\mathrm{M} 2$.

It is noteworthy that quartz-plagioclase-kyanite-garnetzoisite-bearing layers in eclogites from the southern Lévézou and Marvejols massifs in the EMC have been interpreted as high-pressure trondhjemites recording the partial melting of their host rocks (Nicollet and Leyreloup, 1978). Consequently, our results may be taken as a first step for further research of evidence of partial melting, and its consequences, in the eclogites in the EMC. Indeed, partial melting of high-pressure rocks has implications on the rheology of subducted lithospheres (e.g. Labrousse et al., 2011, 2015; Wang et al., 2014), metasomatism of the overlying mantle and related contribution to arc magmatism (e.g. Prouteau et al., 1999, 2001; Borghini et al., 2019; Hernández-Uribe et al., 2020).

\subsection{P-T evolution}

The metamorphic evolution of the studied sample is recorded by three metamorphic stages. During the M1 stage, the rock underwent the crystallization of a garnet- and omphacite-bearing but plagioclase-free assemblage typical for eclogite-facies metamorphism. The development of the eclogite assemblage was coeval with a ductile deformation (materialised by the preferential orientation of the now pseudomorphed kyanite crystals). The inferred M2 assemblage includes garnet 2 and albite. The presence of omphacite, albeit anhedral, in garnet2 and the results of the $P-T$ pseudosections suggest that clinopyroxene was also present in the assemblage, and M2 may then represent a high-pressure granulite-facies metamorphism. During the M3 stage, former porphyroblasts were partially or fully replaced by diopside-amphiboleplagioclase- and corundum/spinel-plagioclase-bearing symplectites, suggesting an equilibration under HT amphibolite- to LP granulite-facies conditions. Taken together these three stages characterize a clockwise $P-T$ path.

The M1 metamorphic stage can be traced through the inclusion suite in garnet. The disappearance of hydrated phases 
(a)

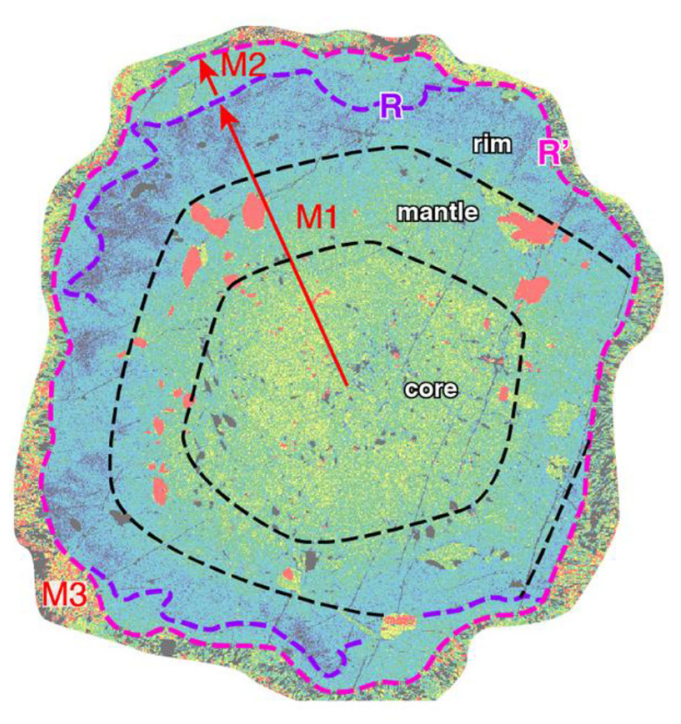

(b)

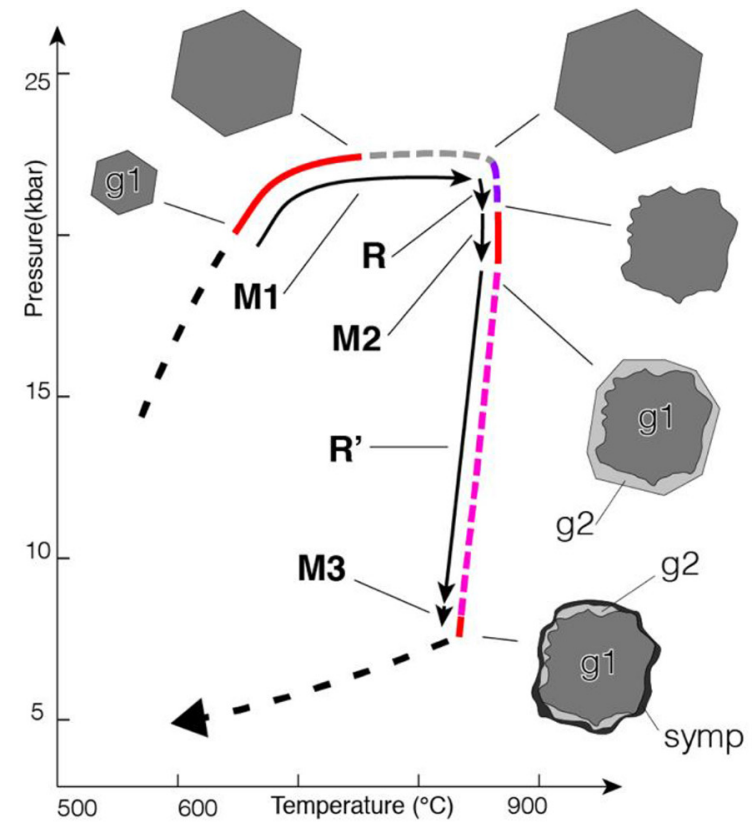

Fig. 8. (a) Calcium X-ray map of garnet and the immediate symplectite rim showing the textural evidences of garnet growth and resorption sequence (same garnet grain as in Fig. 3). Concentric zones (core, mantle and rim) can be traced according to the inclusion pattern in garnet1. Note that the resorption surface $(\mathrm{R})$ is characterized by contrasting Ca content in garnet1 rim and garnet2. (R') marks the current contour of garnet. (b) Synthetic $P-T$ path and schematic pictures of the inferred garnet growth and resorption sequence.

- amphibole and epidote - from the core to the rim of garnet typifies prograde metamorphism from $\sim 20 \mathrm{kbar}-650{ }^{\circ} \mathrm{C}$ to $\sim 22.5 \mathrm{kbar}-750^{\circ} \mathrm{C}$, quantified using the compositional zoning of garnet. Further analysis of the garnet growth zoning suggests that such prograde metamorphism was initially dominated by burial (pressure increase), followed by isobaric heating (temperature increase).

Petrographic observations indicate that a portion of garnet grown during the M1 metamorphism was subsequently partly resorbed (Fig. 8a). This leaves an incertitude on the peak $P-T$ conditions for this metamorphic event. However, two observations can be used to tentatively infer the trend of the missing portion of the $P-T$ path: 1$)$ the preserved garnet1 growth zoning indicates an isobaric heating during M1 (Fig. $5 \mathrm{a})$, and 2) the growth of garnet 2 requires either isothermal decompression or heating in the field melt-amp-cpx-g-pl-kspky-q-ru (Fig. 6a). It must be emphasized that garnet 2 could not have grown during cooling. Therefore, unless the rock underwent an unusual $P-T$ evolution, it can be deduced that the peak $P-T$ conditions for the M1 stage did not significantly exceed $22.5 \mathrm{kbar}$ and $880^{\circ} \mathrm{C}$ (Fig. $8 \mathrm{~b}$ ).

Based on textural features supported by thermodynamic modelling, it is inferred that the M2 assemblage comprised garnet2, albite, amphibole, quartz, rutile, clinopyroxene, kyanite and a K-rich mineral. Pseudosection modelling indicates that garnet mode decreases in the plagioclase-free fields but increases in a small region with plagioclase, amphibole and kyanite (light blue fields in Fig. 6a) through a decrease of pressure, possibly associated with an increase of temperature. This path also accounts for the renewed growth of amphibole and the anhedral shape of clinopyroxene, both observed in garnet2. The transition from the eclogite to the high-pressure granulite facies therefore results from a decompression associated or not with heating toward $19 \mathrm{kbar}$, $875^{\circ} \mathrm{C}$ following the significant temperature increase, under eclogite-facies conditions, during M1 (Fig. 6a).

The M3 metamorphic stage is evidenced by the pervasive replacement of the former high-pressure minerals by symplectites. Pseudosection modelling indicates a strong decompression to $\mathrm{P}<9 \mathrm{kbar}$ along a steep retrograde $P-T$ path associated with a slight to moderate cooling to $750-850{ }^{\circ} \mathrm{C}$ (Fig. 8b).

\subsection{Geodynamic implications}

The peak $P-T$ conditions reported in this study indicate a high-pressure metamorphism, consistent with the discovery of coesite in the Monts-du-Lyonnais area $(28 \mathrm{kbar}$; Lardeaux et al., 2001) and recent petrological works in the EMC (Najac massif, 15-20 kbar, Lotout et al., 2018; Lévézou massif, 18$23 \mathrm{kbar}$, Lotout et al., 2020). The initial prograde metamorphism shows a high $\mathrm{dP} / \mathrm{dT}$ gradient compatible with burial in a subduction zone in agreement with the accepted interpretation of the eclogites in the EMC (Nicollet, 1978; Matte and Burg, 1981; Mercier et al., 1991; Lardeaux et al., 2001; Faure et al., 2014; Lotout et al., 2018). Furthermore, the decompression path associated with limited cooling agrees with the $P-T$ path reported by Lotout et al. (2020) in the Lévézou. The most interesting aspect of the inferred $P-T$ path is to unveil an isobaric heating of $\sim 150{ }^{\circ} \mathrm{C}$ during the prograde metamorphism. Such heating may be accomplished by either thermal equilibration, shear heating, or a "contact" metamorphism.

The achievement of conductive thermal reequilibration may take several tens Myr (England and Thompson, 1984). 
This could a priori reconcile the $430 \mathrm{Ma}$ age inferred for the eclogite facies metamorphism in the LAC of the HA (Ducrot et al., 1983) and subsequent exhumation during crustal nappe stacking at $360 \mathrm{Ma}$ (Gardien et al., 2011). However, this interpretation is unlikely for several reasons. As previously mentioned, the zircon population dissolution method used by Ducrot et al. (1983) has been shown to produce incorrect results especially if zircons are zoned (Paquette et al., 2017). Furthermore, there is growing evidence of a Devonian rather than Silurian age for the Variscan subduction in France (Bosse et al., 2000, 2005; Paquette et al., 2017) and in the EMC in particular (Lotout et al., 2018, 2020). Paquette et al. (2017) proposed that the Silurian ages obtained by dissolution of zircon population resulted from an over-interpretation of the $\mathrm{U}-\mathrm{Pb}$ data. Finally, several studies argued that the preservation of garnet growth zoning implies a short-time residence at high temperature (e.g. Rötzler and Romer, 2001; O'Brien and Rötzler, 2003; Caddick et al., 2010) difficult to reconcile with the hypothesis of conductive thermal reequilibration. As a consequence, our data do not support this hypothesis.

Deciphering the possible influence of shear heating, or a "contact" metamorphism (e.g. by the juxtaposition of a hot mantle) may be harder. In the classic form, shear heating may explain a temperature rise of up to $\sim 200^{\circ} \mathrm{C}$ on a hectometre to kilometre scale along shear zones (e.g. Camacho et al., 2001; Duprat-Oualid et al., 2013; Duretz et al., 2014; Schmalholz and Duretz, 2015). However, deformation-generated viscous dissipation on the lithospheric scale (also termed "viscous heating") is comparable to or even exceeds bulk radiogenic heat production within the crust and may affect the thermicity of a subduction zone and explain regional-scale HT metamorphism (Burg and Gerya, 2005; Gerya et al., 2008). An alternative interpretation for similar heating involves the juxtaposition of a hot mantle with the studied samples (e.g. Dragovic et al., 2015; Massonne, 2006; Liu et al., 2019) that may apply to a regional scale HT metamorphism.

In the EMC, the LAC and the UGU display striking similarities regarding the shape of their $P-T$ path (i.e. HT decompression from HP conditions). Indeed, the eclogites from the LAC record a retrogression under HT amphibolite to granulites facies (e.g. Mercier et al., 1991 and references therein) confirmed by recent petrological data (Monts du Lyonnais: $\sim 750{ }^{\circ} \mathrm{C}-\sim 10$ kbar, Lardeaux et al., 2001; Lévézou: $\sim 600^{\circ} \mathrm{C}, 9 \mathrm{kbar}$, Lotout et al., 2020; HA: $750-850^{\circ} \mathrm{C},<9 \mathrm{kbar}$, this study) and the HP kybearing granulites of the UGU underwent partial melting during decompression (Burg, 1977) at temperatures between $700-800^{\circ} \mathrm{C}$ (Gardien et al., 2011; Schulz, 2014). The similar shape of the $P-T$ path in the UGU and the LAC led numerous authors to envisage a common decompression history of both units under hightemperature conditions (e.g. Burg et al., 1984; Faure et al., 2009; Lardeaux, 2014). This HT character of the decompression path remains valid despite the apparent pressure difference between the eclogite-devoid portion of the UGU ( $\sim 13 \mathrm{kbar}$; Schulz, 2014) and the LAC ( 22.5 kbar; this study).

Although the lack of reliable geochronological data for the eclogite facies metamorphism and the subsequent HT decompression in the HA prevents a regional-scale correlation and therefore a definitive interpretation, regional-scale HT metamorphism appears to be a more probable option than a scale-limited shear heating. In the models presented in
Gerya et al. (2008) only rocks that underwent UHP metamorphism $(\mathrm{P}>35 \mathrm{kbar})$ record an isobaric heating and temperatures comparable with those obtained in this study $\left(\sim 900^{\circ} \mathrm{C}\right)$ suggesting that the studied sample was not dragged deep enough in the mantle to undergo a viscous heating of the expected magnitude. Alternatively, the delamination of the lithospheric mantle from the subducted crust may trigger asthenosphere flow (Brun and Faccenna, 2008) that would in turn cause the retreat of the subducting slab and provoke the exhumation of the subducted rocks. Such process may be invoked to explain the isobaric heating up to high temperature and subsequent subisothermal, supposedly rapid exhumation of the studied sample facilitated by the development of a regional scale partial melting (e.g. Labrousse et al., 2011) followed by cooling. The high temperature $\left(\sim 800^{\circ} \mathrm{C}\right)$ recorded by some granulites of the UGU (Gardien et al., 2011) and the late temperature increase recorded by coronitic gabbros (Nicollet et al., 1993) may also be explained by such heat input from the mantle. This interpretation is in line with the mantle delamination and slab rollback mechanism proposed to explain the HT exhumation of the eclogites in the EMC by Matte (2007).

\section{Conclusions}

The studied sample recorded three metamorphic stages. M1 is characterized by an assemblage dominated by garnet, omphacite and kyanite, without plagioclase, indicating eclogite-facies metamorphic conditions. The rimward disappearance of epidote inclusions and the decreasing proportion of primary amphibole in garnet 1 indicates a prograde metamorphism from $20 \mathrm{kbar}$ and $650^{\circ} \mathrm{C}$ to, at least, $22.5 \mathrm{kbar}$ and $750^{\circ} \mathrm{C}$. The trend of garnet growth zoning is interpreted in terms of a prograde path first dominated by burial and then by heating. It is inferred to peak at $\sim 875^{\circ} \mathrm{C}, 22.5 \mathrm{kbar}$. M2 is characterized by an association of garnet 2 and plagioclase together with clinopyroxene, typical for the HP granulite-facies metamorphism, that crystallized around $19.5 \mathrm{kbar}$ and $875^{\circ} \mathrm{C}$.

Both the M1 temperature peak and M2 are inferred to occur at conditions where the rock is predicted to be partially molten. Although no direct evidence for partial melting has been found in the rock studied, HP melts have been described independently in other locations of the EMC. Given the possible geodynamic importance of eclogite-facies partial melting, this aspect would merit to be looked for specifically in other localities of the orogen.

The M3 stage is characterized by the replacement of former HP minerals by symplectites at $<9 \mathrm{kbar}$ and $750-850^{\circ} \mathrm{C}$. This overall evolution defines a clockwise $P-T$ path initially dominated by a pressure increase, then significant isobaric heating and finally by a strong decompression at high temperature. The relatively short duration of this $P-T$ evolution and the probable subsequent fast cooling are suggested by the preservation of garnet growth zoning. Although an orogen cannot be reinterpreted from one sample, the proposed $P-T$ evolution is compatible with a geodynamic environment dominated by subduction, lithospheric mantle delamination and subsequent slab rollback - a scenario that should be tested elsewhere in the Variscan belt. 


\section{Supplementary Material}

Figure S1. The expected garnet zoning for two $P-T$ paths over 50 points using the drive-file function of Theriak-Domino.

Figure S2. The $P-T$ pseudosection below has been computed with the effect of $95 \%$ garnet fractionation considered.

Table S1. Representative analyses of selected minerals.

The Supplementary Material is available at http://www.bsgf.fr/ $10.1051 / \mathrm{bsgf} / 2020016 / \mathrm{olm}$.

Acknowledgments. This work beneficiated the support of the French geological survey (BRGM) as well as an internal Czech Geological Survey grant (\#310400), accorded to P. Pitra. X. Le $\mathrm{Coz}$ is acknowledged for the efficient production of the thin sections. We are grateful for the assistance in SEM observations and EDS analyses of the staff of the CMEBA facility (ScanMAT, University Rennes 1), which received financial support from the Région Bretagne and the European Union (CPER-FEDER 2007-2014). We are also grateful to J. Langlade, for her assistance during the EPMA analyses (Microsonde Ouest, IFRMER, Brest-Plouzané, France).

\section{References}

Berger J, Féménias O, Ohnenstetter D, Bruguier O, Plissart G, et al. 2010. New occurrence of UHP eclogites in Limousin (French Massif Central): Age, tectonic setting and fluid-rock interactions. Lithos 118(3-4): 365-82.

Bodinier JL, Burg JP, Leyreloup A, Vidal H. 1988. Reliques d'un bassin d'arrière-arc subducte, puis obducte dans la region de Marvejols (Massif central). Bulletin de la Société Géologique de France IV(1): 21-33.

Borghini A, Ferrero S, O'Brien PJ, Laurent O, Günter C, Ziemann MA. 2019. Cryptic metasomatic agent measured in situ in Variscan mantle rocks: Melt inclusions in garnet of eclogite, Granulitgebirge, Germany. Journal of Metamorphic Geology n/a(n/a).

Bosse V, Feraud G, Ruffet G, Ballèvre M, Peucat J-J, De Jong K. 2000. Late Devonian subduction and early-orogenic exhumation of eclogite-facies rocks from the Champtoceaux Complex (Variscan belt, France). Geol. J. 35(3-4): 297-325.

Bosse V, Féraud G, Ballèvre M, Peucat J-J, Corsini M. 2005. Rb-Sr and ${ }^{40} \mathrm{Ar} /{ }^{39} \mathrm{Ar}$ ages in blueschists from the Ile de Groix (Armorican Massif, France): Implications for closure mechanisms in isotopic systems. Chemical Geology 220(1-2): 21-45.

Briand B, Piboule M, Bouchardon JL. 1988. Diversite geochimique des metabasites des groupes leptyno-amphiboliques du Rouergue et de Marvejols (Massif Central); origine et implications. Bulletin de la Société Géologique de France IV(3): 489-98.

Brun JP, Faccenna C. 2008. Exhumation of high-pressure rocks driven by slab rollback. Earth and Planetary Science Letters 272(1-2): 1-7.

Burg JP. 1977. Tectonique et microtectonique des séries cristallophylliennes du Haut-Allier et de la vallée de la Truyère: contribution du microscope électronique à transmission à l'étude de la déformation des minéraux dans les zones profondes. $\mathrm{PhD}$ Thesis, Université des Sciences et Techniques du Languedoc.

Burg JP, Matte PJ. 1978. A Cross Section through the French Massif Central and the Scope of its Variscan Geodynamic Evolution. Zeitschrift der Deutschen Geologischen Gesellschaft 429-60.

Burg, J-P, Gerya TV. 2005. The role of viscous heating in Barrovian metamorphism of collisional orogens: thermomechanical models and application to the Lepontine Dome in the Central Alps. Journal of Metamorphic Geology 23: 75-95.

Burg JP, Leyreloup A, Marchand J, Matte P. 1984. Inverted metamorphic zonation and large-scale thrusting in the Variscan Belt: an example in the French Massif Central. Geological Society, London, Special Publications 14(1): 47-61.

Burg JP, Brun JP, Van Den Driessche J. 1990. Le sillon houiller du Massif Central français: faille de transfert pendant l'amincissement crustal de la chaîne. Comptes Rendus de l'Académie des Sciences de Paris, Série II 311(1): 147-52.

Caddick MJ, Konopásek J, Thompson AB. 2010. Preservation of Garnet Growth Zoning and the Duration of Prograde Metamorphism. Journal of Petrology 51(11): 2327-47.

Camacho A, McDougall I, Armstrong R, Braun J. 2001. Evidence for shear heating, Musgrave Block, central Australia. Journal of Structural Geology 23(6): 1007-13.

Carlson W, Schwarze E. 1997. Petrological significance of prograde homogenization of growth zoning in garnet: an example from the Llano Uplift. Journal of Metamorphic Geology 15(5): 631-44.

Cesare B, Ferrero S, Salvioli-Mariani E, Pedron D, Cavallo A. 2009. "Nanogranite" and glassy inclusions: The anatectic melt in migmatites and granulites. Geology 37(7): 627-30.

de Capitani C, Brown TH. 1987. The computation of chemical equilibrium in complex systems containing non-ideal solutions. Geochimica et Cosmochimica Acta 51(10): 2639-52.

de Capitani C, Petrakakis K. 2010. The computation of equilibrium assemblage diagrams with Theriak/Domino software. American Mineralogist 95(7): 1006-16.

de Hoÿm de Marien L, Le Bayon B, Pitra P, Van Den Driessche J, Poujol M, Cagnard F. 2019. Two-stage Variscan metamorphism in the Canigou massif: Evidence for crustal thickening in the Pyrenees. Journal of Metamorphic Geology 37(6): 863-888.

Dragovic B, Baxter EF, Caddick MJ. 2015. Pulsed dehydration and garnet growth during subduction revealed by zoned garnet geochronology and thermodynamic modeling, Sifnos, Greece. Earth and Planetary Science Letters 413: 111-22.

Ducrot J, Lancelot JR, Marchand J. 1983. Datation U-Pb sur zircons de l'éclogite de La Borie (Haut-Allier, France) et conséquences sur l'évolution ante-hercynienne de l'Europe occidentale. Earth and Planetary Science Letters 62(3): 385-94.

Duprat-Oualid S, Yamato P, Pitra P. 2013. Major role of shear heating in intracontinental inverted metamorphism: Inference from a thermo-kinematic parametric study. Tectonophysics 608: 812-831.

Duretz T, Schmalholz SM, Podladchikov YY, Yuen DA. 2014. Physics-controlled thickness of shear zones caused by viscous heating: Implications for crustal shear localization. Geophysical Research Letters 41(14): 4904-11.

England PC, Thompson AB. 1984. Pressure-Temperature-Time Paths of Regional Metamorphism I. Heat Transfer during the Evolution of Regions of Thickened Continental Crust. Journal of Petrology 25(4): 894-928.

Ernst WG, Liou JG. 2008. High- and ultrahigh-pressure metamorphism: Past results and future prospects. American Mineralogist 93 (11-12): 1771-86.

Faure M, Lardeaux JM, Ledru P. 2009. A review of the pre-Permian geology of the Variscan French Massif Central. Comptes Rendus Geoscience 341(2): 202-213.

Faure M, Cocherie A, Gaché J, Esnault C, Guerrot C, et al. 2014. Middle Carboniferous intracontinental subduction in the Outer Zone of the Variscan Belt (Montagne Noire Axial Zone, French Massif Central): multimethod geochronological approach of polyphase metamorphism. Geological Society, London, Special Publications 405(1): 289-311. 
Forestier FH. 1961. Métamorphisme hercynien et antéhercynien dans le bassin du haut-Allier (Massif Central français). Thesis, Faculté des Sciences de l'Université de Clermont-Ferrand.

Forestier FH, Lasnier B. 1969. Découverte de niveaux d'amphibolites à pargasite, anorthite, corindon et saphirine dans les schistes cristallins de la vallée du Haut-Allier. Contributions to Mineralogy and Petrology 23(3): 194-235.

Forestier FH, Lasnier B, Leyreloup A, Marchand J. 1973. Vues nouvelles sur la catazone dans le Massif Central francais et le Massif Armoricain, de l'affleurement au Moho. Bulletin de la Société Géologique de France S7-XV(5-6): 562-78.

Gardien V, Lardeaux JM, Misseri M. 1988. Les péridotites des Monts du Lyonnais (M.C.F.): témoins privilégiés d'une subduction de lithosphère paléozoïque. Comptes rendus de l'Académie des sciences. Série 2, Mécanique, Physique, Chimie, Sciences de l'univers, Sciences de la Terre 307(19): 1967-72.

Gardien V, Tegyey M, Lardeaux JM, Misseri M, Dufour E. 1990. Crust-mantle relationships in the French Variscan chain: the example of the Southern Monts du Lyonnais unit (eastern French Massif Central). Journal of Metamorphic Geology 8(5): 477-92.

Gardien V, Vanderhaeghe O, Arnaud N, Cocherie A, Grange M, Lécuyer C. 2011. Thermal maturation and exhumation of a middle orogenic crust in the Livradois area (French Massif Central). Bulletin de la Société Géologique de France 182(1): 5-24.

Gerya TV, Perchuk LL, Burg JP. 2008. Transient hot channels: Perpetrating and regurgitating ultrahigh-pressure, high-temperature crust-mantle associations in collision belts. Lithos 103(1): 236-56.

Giraud A, Marchand J, Dupuy C, Dostal J. 1984. Geochemistry of leptyno-amphibolite complex from Haut Allier (French Massif Central). Lithos 17: 203-14.

Girardeau J, Dubuisson G, Mercier JC. 1986. Cinematique de mise en place des ophiolites et nappes crystallophiliennes du Limousin, Ouest du Massif Central francais. Bulletin de la Société Géologique de France II(5): 849-60.

Godard G. 2001. Eclogites and their geodynamic interpretation: a history. Journal of Geodynamics 32(1): 165-203.

Green ECR, White RW, Diener JFA, Powell R, Holland TJB, Palin RM. 2016. Activity-composition relations for the calculation of partial melting equilibria in metabasic rocks. Journal of Metamorphic Geology 34(9): 845-69.

Hernández-Uribe D, Hernández-Montenegro JD, Cone KA, Palin RM. 2020. Oceanic slab-top melting during subduction: Implications for trace-element recycling and adakite petrogenesis. Geology 48(3): 216-20.

Holland T, Powell R. 2003. Activity-composition relations for phases in petrological calculations: an asymmetric multicomponent formulation. Contributions to Mineralogy and Petrology 145(4): 492-501.

Holland TJB, Powell R. 2011. An improved and extended internally consistent thermodynamic dataset for phases of petrological interest, involving a new equation of state for solids. Journal of Metamorphic Geology 29(3): 333-83.

Jamieson RA, Beaumont C, Fullsack P, Lee B. 1998. Barrovian regional metamorphism: where's the heat? Geological Society, London, Special Publications 138(1): 23-51.

Karabinos P. 1984. Polymetamorphic garnet zoning from southeastern Vermont. Am J Sci 284(9): 1008-25.

Kroner U, Romer RL. 2013. Two plates-Many subduction zones: The Variscan orogeny reconsidered. Gondwana Research 24(1): 298-329.

Labrousse L, Prouteau G, Ganzhorn A-C. 2011. Continental exhumation triggered by partial melting at ultrahigh pressure. Geology 39(12): 1171-74.

Labrousse L, Duretz T, Gerya T. 2015. $\mathrm{H}_{2} \mathrm{O}$-fluid-saturated melting of subducted continental crust facilitates exhumation of ultrahigh- pressure rocks in continental subduction zones. Earth and Planetary Science Letters 428: 151-61.

Lardeaux JM. 2014. Deciphering orogeny: a metamorphic perspective Examples from European Alpine and Variscan belts. Bulletin de la Société Géologique de France 185(5): 281-310.

Lardeaux JM, Ledru P, Daniel I, Duchene S. 2001. The Variscan French Massif Central- a new addition to the ultra-high pressure metamorphic "club": exhumation processes and geodynamic consequences. Tectonophysics 332(1-2): 143-67.

Lasnier B. 1968. Decouverte de roches eclogitiques dans le groupe leptyno-amphibolique des Monts du Lyonnais (Massif Central francais). Bulletin de la Société Géologique de France S7-X(2): 179-85.

Lasnier B. 1977. Persistance d'une série granulitique au coeur du Massif Central français, Haut-Allier: les termes basiques, ultrabasiques et carbonatés. Thesis, Université de Nantes, Laboratoire de pétrologie et de minéralogie.

Laurent O, Couzinié S, Zeh A, Vanderhaeghe O, Moyen JF, et al. 2017. Protracted, coeval crust and mantle melting during Variscan late-orogenic evolution: $\mathrm{U}-\mathrm{Pb}$ dating in the eastern French Massif Central. Int J Earth Sci (Geol Rundsch) 106(2): 421-51.

Le Fort P. 1986. Metamorphism and magmatism during the Himalayan collision. Geological Society, London, Special Publications 19(1): 159-72.

Leake BE, Woolley AR, Arps CES, Birch WD, Gilbert MC, et al. 1997. Nomenclature of amphiboles; Report of the Subcommittee on Amphiboles of the International Mineralogical Association, Commission on New Minerals and Mineral Names. American Mineralogist 82(9-10): 1019-37.

Ledru P, Lardeaux JM, Santallier D, Autran A, Quenardel JM, et al. 1989. Où sont les nappes dans le Massif central français? Bulletin de la Société géologique de France 8(3): 605-618.

Liu Q, Hermann J, Zheng S, Zhang J. 2019. Evidence for UHP anatexis in the Shuanghe UHP paragneiss from inclusions in clinozoisite, garnet and zircon. Journal of Metamorphic Geology 2 (38): 129-55.

Lotout C, Pitra P, Poujol M, Anczkiewicz R, Van Den Driessche J. 2018. Timing and duration of Variscan high-pressure metamorphism in the French Massif Central: A multimethod geochronological study from the Najac Massif. Lithos 308-309: 381-94.

Lotout C, Poujol M, Pitra P, Anczkiewicz R, Van Den Driessche J. 2020. From burial to exhumation: emplacement and metamorphism of mafic eclogitic terranes constrained through multimethod petrochronology, case study from the Lévézou massif (French Massif Central, Variscan belt). Journal of Petrology (In press). DOI: $10.1093 /$ petrology/egaa046.

Marchand J. 1974. Persistance d'une série granulitique au coeur du Massif Central français, Haut-Allier: les termes acides. Université de Nantes.

Massonne HJ. 2006. Early metamorphic evolution and exhumation of felsic high-pressure granulites from the north-western Bohemian Massif. Mineralogy and Petrology 86(3): 177-202.

Matte P. 1986. Tectonics and plate tectonics model for the Variscan belt of Europe. Tectonophysics 126(2): 329-374.

Matte P. 2007. Variscan thrust nappes, detachments, and strike-slip faults in the French Massif Central: Interpretation of the lineations. In: Geological Society of America Memoirs, Vol.200, pp.391402. Geological Society of America.

Matte P, Burg JP. 1981. Sutures, thrusts and nappes in the Variscan Arc of western Europe: plate tectonic implications. Geological Society, London, Special Publications 9(1): 353-58.

Mercier L, Lardeaux JM, Davy P. 1991. On the tectonic significance of retrograde P-T-t paths in eclogites of the French Massif Central. Tectonics 10(1): 131-40. 
Miyashiro A. 1961. Evolution of Metamorphic Belts. Journal of Petrology 2(3): 277-311.

Miyashiro A. 1972. Metamorphism and related magmatism in plate tectonics. American Journal of Science 272(7): 629-56.

Nicollet C. 1978. Pétrologie et tectonique des terrains cristallins antépermiens du versant sud du dôme du Lévezou (Rouergue, Massif central). Bulletin BRGM. 1(3): 225-63.

Nicollet C, Leyreloup A. 1978. Pétrologie des niveaux trondhjémitiques de haute pression associés aux éclogites et amphibolites des complexes leptyno-amphiboliques du Massif Central français. Canadian Journal of Earth Sciences 15(5): 696-707.

Nicollet C, Lahlafi M, Lasnier B. 1993. Occurence of a late Hercynian metamorphic event, of low pressure granulitic conditions, in the Haut-Allier (French Massif Central): geodynamic implications. Comptes Rendus de l'Académie des Sciences 317: 1609-15.

O’Brien PJ, Rötzler J. 2003. High-pressure granulites: formation, recovery of peak conditions and implications for tectonics. Journal of Metamorphic Geology 21(1): 3-20.

Paquette JL, Monchoux P, Couturier M. 1995. Geochemical and isotopic study of a norite-eclogite transition in the European Variscan belt: Implications for $\mathrm{U} / \mathrm{Pb}$ zircon systematics in metabasic rocks. Geochimica et Cosmochimica Acta 59(8): 1611-22.

Paquette JL, Ballèvre M, Peucat JJ, Cornen G. 2017. From opening to subduction of an oceanic domain constrained by LA-ICP-MS U-Pb zircon dating (Variscan belt, Southern Armorican Massif, France). Lithos 294-295: 418-37.

Piboule M. 1977. Utilisation de l'analyse factorielle discriminante pour la reconnaissance de la nature des magmas parents des amphibolites; application à quelques métabasites du Rouergue et du Limousin (Massif central français). Bulletin de la Société Géologique de France S7-XIX(5): 1133-43.

Piboule M, Briand B. 1985. Geochemistry of eclogites and associated rocks of the southeastern area of the French Massif Central: Origin of the protoliths. Chemical Geology 50(1): 189-99.

Pin C, Lancelot J. 1982. U-Pb dating of an early paleozoic bimodal magmatism in the french Massif Central and of its further metamorphic evolution. Contributions to Mineralogy and Petrology 79(1): $1-12$

Pin C, Vielzeuf D. 1988. Les granulites de haute-pression d'Europe moyenne témoins d'une subduction eo-hercynienne; implications sur l'origine des groupes leptyno-amphiboliques. Bulletin de la Société Géologique de France IV(1): 13-20.

Prouteau G, Scaillet B, Pichavant M, Maury RC. 1999. Fluid-present melting of ocean crust in subduction zones. Geology 27(12): 1111-14.

Prouteau G, Scaillet B, Pichavant M, Maury R. 2001. Evidence for mantle metasomatism by hydrous silicic melts derived from subducted oceanic crust. Nature 410(6825): 197-200.

Rötzler J, Romer RL. 2001. P-T-t Evolution of Ultrahigh-Temperature Granulites from the Saxon Granulite Massif, Germany. Part I: Petrology. Journal of Petrology 42(11): 1995-2013.

Santallier D, Briand B, Menot RP, Piboule M. 1988. Les complexes leptyno-amphiboliques (CLA): revue critique et suggestions pour un meilleur emploi de ce terme. Bulletin de la Société Géologique de France 1: 3-12.

Schmalholz SM, Duretz T. 2015. Shear zone and nappe formation by thermal softening, related stress and temperature evolution, and application to the Alps. Journal of Metamorphic Geology 33(8): 887-908.
Schulz B. 2014. Early Carboniferous P-T path from the Upper Gneiss Unit of Haut-Allier (French Massif Central) - reconstructed by geothermobarometry and EMP-Th-U-Pb monazite dating. $J$ Geosci 59(4): 327-49.

Schulz B, Triboulet C, Audren C, Feybesse J-L. 1996. Zoned garnets in metapelites and P-T-deformation path interpretation of the Variscan inverted metamorphic sequence of Haut-Allier, French Massif Central. Zeitschrift der Deutschen Geologischen Gesellschaft 147(2): 249-73.

Spear FS. 1993. Metamorphic Phase Equilibria And PresureTemperature-Time-Paths. Mineralogical Society of America 799.

Spear FS, Selverstone J, Hickmott D, Crowley P, Hodges KV. 1984. P-T paths from garnet zoning: A new technique for deciphering tectonic processes in crystalline terranes. Geology 12(2): 87-90.

Stampfli GM, Hochard C, Vérard C, Wilhem C, vonRaumer J. 2013. The formation of Pangea. Tectonophysics 593: 1-19.

Štípská P, Pitra P, Powell R. 2006. Separate or shared metamorphic histories of eclogites and surrounding rocks? An example from the Bohemian Massif. Journal of Metamorphic Geology 24(3): 219-40.

Thompson AB, Connolly JAD. 1990. Metamorphic fluids and anomalous porosities in the lower crust. Tectonophysics 182(1): 47-55.

Thompson AB, Tracy RJ, Lyttle PT, Thompson JB. 1977. Prograde reaction histories deduced from compositional zonation and mineral inclusions in garnet from the Gassetts schist, Vermont. American Journal of Science 277(9): 1152-67.

Tual L, Pitra P, Möller C. 2017. P-T evolution of Precambrian eclogite in the Sveconorwegian orogen, SW Sweden. Journal of Metamorphic Geology 35(5): 493-515.

Vanderhaeghe O. 2012. The thermal-mechanical evolution of crustal orogenic belts at convergent plate boundaries: A reappraisal of the orogenic cycle. Journal of Geodynamics 56-57: 124-45.

Wang L, Kusky TM, Polat A, Wang S, Jiang X, et al. 2014. Partial melting of deeply subducted eclogite from the Sulu orogen in China. Nature Communications 5: 5604.

White RW, Powell R, Clarke GL. 2002. The interpretation of reaction textures in Fe-rich metapelitic granulites of the Musgrave Block, central Australia: constraints from mineral equilibria calculations in the system $\mathrm{K}_{2} \mathrm{O}-\mathrm{FeO}-\mathrm{MgO}-\mathrm{Al}_{2} \mathrm{O}_{3}-\mathrm{SiO}_{2}-\mathrm{H}_{2} \mathrm{O}-\mathrm{TiO}_{2}-\mathrm{Fe}_{2} \mathrm{O}_{3}$. Journal of Metamorphic Geology 20(1): 41-55.

White RW, Powell R, Holland TJB, Johnson TE, Green ECR. 2014a. New mineral activity-composition relations for thermodynamic calculations in metapelitic systems. Journal of Metamorphic Geology 32(3): 261-86.

White RW, Powell R, Johnson TE. 2014b. The effect of Mn on mineral stability in metapelites revisited: new $\mathrm{a}-\mathrm{x}$ relations for manganese-bearing minerals. Journal of Metamorphic Geology 32 (8): 809-28.

White RW, Powell R, Holland TJB, Worley BA. 2000. The effect of $\mathrm{TiO} 2$ and $\mathrm{Fe} 2 \mathrm{O} 3$ on metapelitic assemblages at greenschist and amphibolite facies conditions: mineral equilibria calculations in the system $\mathrm{K}_{2} \mathrm{O}-\mathrm{FeO}-\mathrm{MgO}-\mathrm{Al}_{2} \mathrm{O}_{3}-\mathrm{SiO}_{2}-\mathrm{H}_{2} \mathrm{O}-\mathrm{TiO}_{2}-\mathrm{Fe}_{2} \mathrm{O}_{3}$. Journal of Metamorphic Geology 18(5): 497-511.

Zhang RY, Liou JG, Ernst WG. 1995. Ultrahigh-pressure metamorphism and decompressional P-T paths of eclogites and country rocks from Weihai, eastern China. Island Arc 4(4): 293-309.

Zuluaga CA, Stowell HH, Tinkham DK. 2005. The effect of zoned garnet on metapelite pseudosection topology and calculated metamorphic P-T paths. American Mineralogist 90(10): 1619-28.

Cite this article as: de Hoÿm de Marien L, Pitra P, Cagnard F, Le Bayon B. 2020. Prograde and retrograde $P-T$ evolution of a Variscan hightemperature eclogite, French Massif Central, Haut-Allier, BSGF - Earth Sciences Bulletin 191: 14. 